\title{
Critical Limits for Soybean and Black Bean Root Growth, Based on Macroporosity and Penetrability, for Soils with Distinct Texture and Management Systems
}

\author{
Luis Eduardo Akiyoshi Sanches Suzuki ${ }^{1} \mathbb{D}$, Dalvan José Reinert ${ }^{2} \mathbb{D}$, Marlene Cristina Alves ${ }^{3}$ \\ and José Miguel Reichert $2, *$ (D) \\ 1 Center of Technology Development, Federal University of Pelotas, \\ Pelotas 96010-610, Rio Grande do Sul State, Brazil; luis.suzuki@ufpel.edu.br \\ 2 Soils Department, Federal University of Santa Maria (Universidade Federal de Santa Maria-UFSM), \\ Santa Maria 97105-9000, Rio Grande do Sul State, Brazil; dalvan@ufsm.br \\ 3 Faculty of Engineering, São Paulo State University, Ilha Solteira 15385-000, São Paulo State, Brazil; \\ mcalves@agr.feis.unesp.br \\ * Correspondence: reichert@ufsm.br
}

\section{check for}

Citation: Suzuki, L.E.A.S.; Reinert,

D.J.; Alves, M.C.; Reichert, J.M.

Critical Limits for Soybean and Black Bean Root Growth, Based on Macroporosity and Penetrability, for Soils with Distinct Texture and Management Systems. Sustainability 2022, 14, 2958. https://doi.org/ $10.3390 /$ su14052958

Academic Editor: Cristian-Valeriu Patriche

Received: 4 February 2022

Accepted: 2 March 2022

Published: 3 March 2022

Publisher's Note: MDPI stays neutral with regard to jurisdictional claims in published maps and institutional affiliations.

Copyright: () 2022 by the authors Licensee MDPI, Basel, Switzerland. This article is an open access article distributed under the terms and conditions of the Creative Commons Attribution (CC BY) license (https:// creativecommons.org/licenses/by/ $4.0 /)$.

\begin{abstract}
Soil compaction is a worldwide problem in agricultural areas, and it is important to define soil properties and reference values that allow knowledge of the compaction level for decision making. The objective of this study was to define the critical values of physical properties associated with the compaction of soils. Three Ultisols and two Oxisols, under different management systems, were collected at different depths for an evaluation of particle size, volumetric moisture, bulk density, and porosity. In the field, soil resistance to penetration and the root length of the soybean and edible black bean crop were measured. The soil profiles presented horizontal layers with similar resistance, but in some cases, there is discontinuity of these layers, which allows the roots to use the zones of lower resistance to deepen in the profile. The values of bulk density and resistance to penetration critical to soybean and edible black bean (only in sandy loam soil) root growth, according to soil textural class, are: sandy loam $=1.66 \mathrm{Mg} \mathrm{m}^{-3}$ and 1.5 to $2 \mathrm{MPa}$; loam and clay loam $=1.52 \mathrm{Mg} \mathrm{m}^{-3}$ and 1 to $1.5 \mathrm{MPa}$; silty clay loam and silty clay $=1.32 \mathrm{Mg} \mathrm{m}^{-3}$ and 1.5 to $2 \mathrm{MPa}$; and clay $=1.33$ to $1.36 \mathrm{Mg} \mathrm{m}^{-3}$ and 2 to $3.5 \mathrm{MPa}$.
\end{abstract}

Keywords: critical bulk density; critical macroporosity; profile of soil resistance to penetration; soil compaction; soil management; no-tillage; chiseling

\section{Introduction}

Soil compaction is a worldwide problem in agricultural areas. With soil compaction, there are several negative effects on soil functioning, from its direct interference on nutrient uptake by plants, such as phosphorus and potassium that are absorbed by plants by diffusion, to reduced crop productivity, increased production costs, and reduction in leaf area due to the increased production of abscisic acid by plant roots [1]. Reduced root growth and changes in soil physical properties due to compaction have been observed in many crops, such as soybean [2-7], corn [8-12], wheat [13-16], edible black beans [17-24], rice [25,26], cassava [27-31], onions [32], Crambe [33], sugarcane [34,35], tobacco [36], cover crops [37,38], pastures/grasslands [39-45], and forest plantations [46-51].

In several of these studies, the existing compaction state was increased by additional wheeling, or compaction alleviation was tested by tillage (inversion and/or chiseling) and the use of cover crops. Nonetheless, only few of these studies searched for critical limits for root growth and crop yield. Furthermore, it is important to stress the existence of a feedback mechanism where, for instance, soil fertility affects the plant's response to soil compaction. For example, wheat growth in response to physical impairment in the soil is dependent on the availability of P [52]. 
Given the need to implement sustainable soil management to recover degraded soils and improve soil health, providing food and clean water, maintaining biodiversity, ensuring carbon sequestration, and increasing resilience to climate change, it is necessary, among others actions, to prevent and mitigate soil compaction [53]. For more sustainable soil management, it is important to define soil properties and reference values that allow a knowledge of the compaction levels for decision making regarding compacted layer management strategies. Among the properties used to identify compacted layers and the effects of soil use and management, bulk density and mechanical resistance to penetration have been widely used. For example, Silva et al. [54] used these properties to identify the level of soil compaction in a watershed, while Queiroz et al. [55] used them to evaluate different agroecosystems in the Brazilian semiarid region.

Soil resistance to penetration indicates the level of compaction and resistance to root penetration, which is used in the assessment of soil quality in agricultural areas and in decision making regarding the need or not of mechanical soil tillage to reduce it and reduce physical restrictions on plant root development [56]. Aiming at better soil management, Spliethoff et al. [57] evaluated the spatial variability of penetration resistance in an experimental area of 0.2 ha with different sampling grids in an Oxisol. Further, Andrade et al. [58] evaluated the spatial variability of soil resistance to penetration in coffee plantations to obtain information about compaction and support decision making regarding the performance of the subsoiling operation.

Some studies indicated bulk density values [4,36,59-62] and resistance to penetration [59,63-66] as being critical or limiting to plant root growth. However, there is still a need for further studies to validate those values already identified or to present new values. In addition, crops have different responses to soil limitations; soil bulk density is dependent on soil texture [19] and penetration resistance varies according to soil moisture, bulk density, and texture [38,67-69] according to the three-dimensional variability of the soil and the presence of biopores in compacted soil layers [13,70-72] that enable root growth. All these variables make it difficult to define critical or limiting values for plants, but they should be pursued.

Therefore, the objective of this work was to define the critical values of some physical properties associated with the compaction of Ultisols and Oxisols submitted to different management systems.

\section{Materials and Methods}

To carry out this study, five soils in five municipalities from Rio Grande do Sul State (Figure 1), Brazil, under different management systems, were studied in the first semester of 2004. Although the data are from 2004, this scientific topic is still current and relevant, since there is still little information available on critical values, especially bulk density and soil resistance to penetration associated to soil compaction in soils with different texture. The soils under study were: Argissolo Vermelho Distrófico arênico, Argissolo Vermelho Distrófico latossólico, Argissolo Vermelho-Amarelo Alumínico típico, Latossolo Vermelho Distrófico típico, and Latossolo Vermelho Aluminoférrico típico, according to the "Brazilian System of Soil Classification" [73] or, respectively, Ultisols and Oxisols [74].

In some soils, the sampling was carried out at the headboard/turning point of the planting area, searching for samples with higher levels of soil bulk density, resulting in samples with a range of bulk density values, including values that may be critical for root growth and/or represent soil physical degradation. During the conduction of this study, with the exception of the chisel management of Argissolo Vermelho Distrófico arênico (Ultisol), which had edible black bean crop in the area, the other managements were with soybean crop. The managements/tillage in each soil and the weather conditions [75] were as follows:

(1) Argissolo Vermelho Distrófico arênico (Ultisol): Soil sampling in an experimental plot and production area of the Department of Soils of the Federal University of Santa Maria (UFSM), municipality of Santa Maria, Rio Grande do Sul State, at $151 \mathrm{~m}$ altitude, 
with the following managements: experimental plot in which it received chiseling in the year 2002 and no-tillage in the following years, and prior to chiseling it had been under no-tillage for approximately 8 years (Chisel); production area for 12 years under no-tillage (NT); and headboard/turning point of the area for 12 years under no-tillage (NTC). The annual climatic characteristics of the municipality are: minimum, average, and maximum temperature of, respectively, $6.3{ }^{\circ} \mathrm{C}, 19.2{ }^{\circ} \mathrm{C}$, and $25.2{ }^{\circ} \mathrm{C}$; average relative humidity of $77 \%$; and accumulated rainfall of $1624.9 \mathrm{~mm}$;

(2) Argissolo Vermelho Distrófico latossólico (Ultisol): Soil sampling from two farms in the municipality of São Sepé, Rio Grande do Sul State, at $85 \mathrm{~m}$ altitude, with managements: Farm 1-four years under no-tillage, with pasture cultivated prior to the beginning of the notillage system (NT); headboard/turning point of farm 1 (NTC 1); Farm 2-potato cultivation in 2002 and no-tillage in the following years (potato); and Farm 2-headboard/turning point of the area for four years under no-tillage (NTC 2). The climatic characteristics of the municipality are not available, but the municipality borders Santa Maria (Figure 1);

(3) Argissolo Vermelho-Amarelo Alumínico típico (Ultisol): Soil sampling from two farms in the municipality of Itaara, Rio Grande do Sul State, at $425 \mathrm{~m}$ altitude, with the managements: Farm 1-conventional tillage from 1980 to 1995, and no-tillage in the following years (NT 1); Farm 1 headboard/turning point (NTC); Farm 2-no-tillage since 1986 and in winter there is animal grazing for 90 days in ryegrass sown in the area and harvested (NT 2); and Farm 2-potato planting with conventional tillage in 1998, chiseling in 2000, and no-tillage in the following years (potato). The climatic characteristics of the municipality are not available, but the municipality borders Santa Maria (Figure 1).

(4) Latossolo Vermelho Distrófico típico (Oxisol): Soil sampling in two farms in the municipality of Ibirubá, Rio Grande do Sul State, at $416 \mathrm{~m}$ altitude, with the managements: Farm 1-chiseling in the winter of 2002 and no-tillage in the following years (NT 1); headboard/turning point of farm 1 (NTC 1); Farm 2-chiseling in the winter of 2000 and notillage in the following years (NT 2); and headboard/turning point of farm 2 (NTC 2). The annual climatic characteristics of the municipality are: minimum, average, and maximum temperature of, respectively, $12.8^{\circ} \mathrm{C}, 17.8^{\circ} \mathrm{C}$, and $24.9^{\circ} \mathrm{C}$; average relative humidity of $77 \%$; and accumulated rainfall of $1205.9 \mathrm{~mm}$;

(5) Latossolo Vermelho Aluminoférrico típico (Oxisol): Soil sampling from three farms in the municipality of Campinas do Sul, Rio Grande do Sul State, at $583 \mathrm{~m}$ altitude, with managements: Farm 1-no-tillage for 10-12 years (NT 1); Farm 1-no-tillage for 10-12 years and received chiseling in the winter of 2003 and subsequent sowing of oats (Chisel); Farm 2-pasture cultivated in winter (Pasture); Farm 2-no-tillage for 10 years (NT 2); and Farm 3-no-tillage for 10-12 years (NT 3); and headboard/turning point of farm 3 (NTC). The climatic characteristics of the municipality are not available, but the municipality is near Erechim, with annual minimum, average, and maximum temperature of, respectively, $5.9{ }^{\circ} \mathrm{C}, 18.2^{\circ} \mathrm{C}$, and $23.3^{\circ} \mathrm{C}$; average relative humidity of $79 \%$; and accumulated rainfall of $1737.5 \mathrm{~mm}$.

Soil samples with unpreserved structure were collected in the $0-0.05,0.05-0.10,0.10-0.15$, $0.15-0.20,0.20-0.25$, and $0.25-0.30 \mathrm{~m}$ layers of each soil and passed through a $2.0 \mathrm{~mm}$ mesh sieve to evaluate particle size distribution by the method of pipette [76], with three replicates. The dispersion of soil samples was carried out by horizontal shaking at $120 \mathrm{rpm}$ for $4 \mathrm{~h}$, using $100 \mathrm{~mL}$ "snap cap" glasses containing $20 \mathrm{~g}$ of soil, $10 \mathrm{~mL}$ of $6 \% \mathrm{NaOH}$ (chemical dispersant), $50 \mathrm{~mL}$ of distilled water, and two nylon spheres weighing $3.04 \mathrm{~g}$, diameter $0.0171 \mathrm{~m}$, and density $1.11 \mathrm{Mg} \mathrm{m}^{-3}$ [77]. The clay (particles $<0.002 \mathrm{~mm}$ in diameter) was determined by pipetting, the sand was separated into coarse (diameter between 2 and $0.25 \mathrm{~mm}$ ) and fine (diameter between 0.25 and $0.053 \mathrm{~mm}$ ) by sieving, and the silt (diameter between 0.053 and $0.002 \mathrm{~mm}$ ) by calculating the difference of the sum of clay and sand. The results of particle size distribution were used for their textural classification, in the textural triangle from "National Resource Conservation Service/United States Department of Agriculture" [78]. 


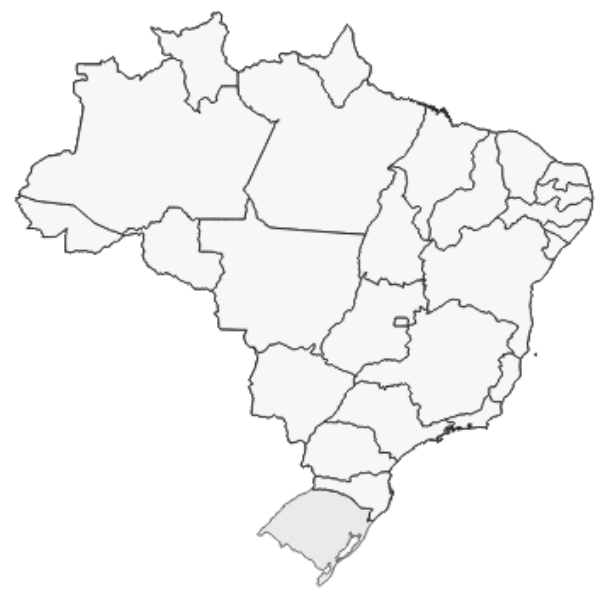

(a)

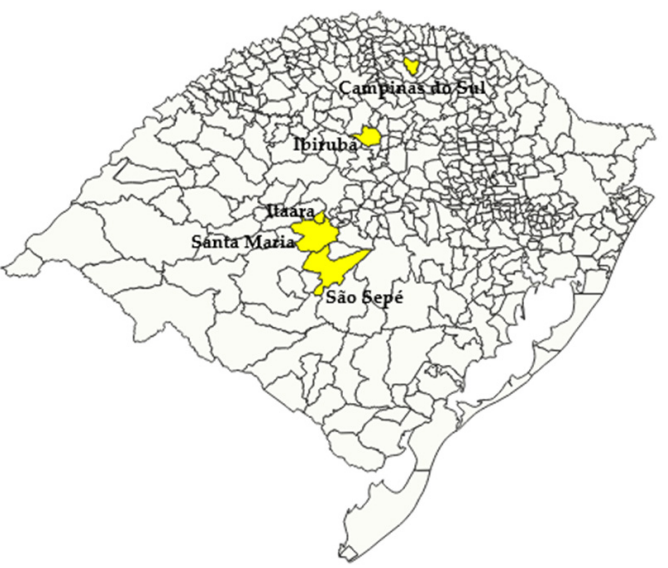

(b)

Figure 1. (a) Map from Brazil, with Rio Grande do Sul State highlighted; (b) map from Rio Grande do Sul State with the municipalities São Sepé, Santa Maria, Itaara, Ibirubá, and Campinas do Sul highlighted. Maps without scale.

To collect soil samples with preserved structure, three trenches were opened in each management, close to each other, thus avoiding variability between samples. In each trench, samples with preserved structure were collected in metal rings of $0.0300 \mathrm{~m}$ in height and $0.0555 \mathrm{~m}$ in diameter in the $0-0.05,0.05-0.10,0.10-0.15,0.15-0.20,0.20-0.25$, and $0.25-0.30 \mathrm{~m}$ soil layers. After preparing the samples, they were saturated by capillarity, weighed, and sent to the tension table, where a tension of $6 \mathrm{kPa}$ was applied. After two days on the tension table, the samples were weighed and dried at a temperature of $105{ }^{\circ} \mathrm{C}$, where they remained for two days and then weighed. After all these procedures, bulk density, total porosity, macroporosity, and microporosity were calculated [76].

Soil mechanical resistance to penetration was quantified in the field with a digital penetrometer brand Remik CP 20 Ultrasonic Cone Penetrometer, manufactured by Agridry Rimik Pty Ltd., Toowoomba City, Australia Country, with electronic data storage and conical tip with a penetration angle of $30^{\circ}$. The readings were taken at every $0.015 \mathrm{~m}$ depth and, with the exception of the Latossolo Vermelho Aluminoférrico, where the readings were taken between the seeding lines, for the other soils the measurements were made at the seeding line and at $0.10,0.20$, and $0.30 \mathrm{~m}$ to the left and to the right of the seedling line, forming a profile of mechanical resistance to penetration.

Volumetric soil moisture at the time of evaluation of mechanical resistance to penetration was obtained from soil samples with preserved structure, for $0-0.05,0.05-0.10$, $0.10-0.15,0.15-0.20,0.20-0.25$, and $0.25-0.30 \mathrm{~m}$ soil layers.

The evaluation of the root growth of soybean (and edible black bean in the chisel management of Argissolo Vermelho Distrófico arênico) was carried out in open trenches at the sampling sites to assess the physical properties of the soil. The trenches were opened until the depth of growth of the root system, which was exposed, and the depth of growth was measured with a measuring tape. In the Latossolo Vermelho Distrófico típico (Oxisol), this evaluation was not performed.

Pearson correlation analysis was performed between the physical properties of the soil.

\section{Results and Discussion}

The soils presented a wide range of granulometric variations and textural classes, with the clay contents between 86 and $612 \mathrm{~g} \mathrm{~kg}^{-1}$ and total sand between 76 and $674 \mathrm{~g} \mathrm{~kg}^{-1}$ (Table 1). 
Table 1. Distribution of particles by size and textural class for the different layers of Ultisols and Oxisols under study.

\begin{tabular}{|c|c|c|c|c|c|c|}
\hline \multirow{3}{*}{ Layer, $\mathbf{m}$} & \multicolumn{3}{|c|}{ Sand } & \multicolumn{3}{|r|}{ Textural } \\
\hline & Total & Coarse & Fine & Silt & Clay & Class \\
\hline & \multicolumn{5}{|c|}{$\mathrm{g} \mathrm{kg}^{-1}$} & \\
\hline \multicolumn{7}{|c|}{ Argissolo Vermelho Distrófico arênico (Ultisol) } \\
\hline $0-0.05$ & 674 & 203 & 471 & 240 & 86 & $\begin{array}{l}\text { Sandy } \\
\text { loam }\end{array}$ \\
\hline $0.05-0.10$ & 660 & 196 & 464 & 237 & 103 & $\begin{array}{c}\text { Sandy } \\
\text { loam }\end{array}$ \\
\hline $0.10-0.15$ & 655 & 187 & 468 & 253 & 92 & $\begin{array}{c}\text { Sandy } \\
\text { loam }\end{array}$ \\
\hline $0.15-0.20$ & 654 & 189 & 465 & 256 & 90 & $\begin{array}{c}\text { Sandy } \\
\text { loam }\end{array}$ \\
\hline $0.20-0.25$ & 653 & 204 & 449 & 253 & 94 & $\begin{array}{l}\text { Sandy } \\
\text { loam }\end{array}$ \\
\hline $0.25-0.30$ & 669 & 200 & 469 & 244 & 87 & $\begin{array}{l}\text { Sandy } \\
\text { loam }\end{array}$ \\
\hline \multicolumn{7}{|c|}{ Argissolo Vermelho Distrófico latossólico (Ultisol) } \\
\hline $0-0.05$ & 439 & 252 & 187 & 350 & 211 & Loam \\
\hline $0.05-0.10$ & 408 & 246 & 162 & 326 & 267 & Loam \\
\hline $0.10-0.15$ & 399 & 245 & 154 & 342 & 259 & Loam \\
\hline $0.15-0.20$ & 389 & 240 & 149 & 336 & 275 & Clay loam \\
\hline $0.20-0.25$ & 358 & 219 & 139 & 324 & 318 & Clay loam \\
\hline $0.25-0.30$ & 354 & 214 & 140 & 308 & 338 & Clay loam \\
\hline \multicolumn{7}{|c|}{ Argissolo Vermelho-Amarelo Alumínico típico (Ultisol) } \\
\hline $0-0.05$ & 161 & 55 & 106 & 503 & 336 & $\begin{array}{c}\text { Silty clay } \\
\text { loam }\end{array}$ \\
\hline $0.05-0.10$ & 149 & 54 & 95 & 468 & 383 & $\begin{array}{l}\text { Silty clay } \\
\text { loam }\end{array}$ \\
\hline $0.10-0.15$ & 146 & 57 & 89 & 459 & 395 & $\begin{array}{l}\text { Silty clay } \\
\text { loam }\end{array}$ \\
\hline $0.15-0.20$ & 144 & 59 & 85 & 443 & 413 & Silty clay \\
\hline $0.20-0.25$ & 133 & 55 & 78 & 442 & 425 & Silty clay \\
\hline $0.25-0.30$ & 123 & 51 & 72 & 428 & 449 & Silty clay \\
\hline \multicolumn{7}{|c|}{ Latossolo Vermelho Distrófico típico (Oxisol) } \\
\hline $0-0.05$ & 345 & 119 & 226 & 227 & 428 & Clay \\
\hline $0.05-0.10$ & 335 & 116 & 219 & 225 & 440 & Clay \\
\hline $0.10-0.15$ & 338 & 112 & 226 & 210 & 452 & Clay \\
\hline $0.15-0.20$ & 338 & 116 & 222 & 202 & 460 & Clay \\
\hline $0.20-0.25$ & 312 & 111 & 201 & 196 & 492 & Clay \\
\hline $0.25-0.30$ & 297 & 108 & 189 & 198 & 505 & Clay \\
\hline \multicolumn{7}{|c|}{ Latossolo Vermelho Aluminoférrico típico (Oxisol) } \\
\hline $0-0.05$ & 127 & 13 & 114 & 368 & 505 & Clay \\
\hline $0.05-0.10$ & 120 & 10 & 110 & 352 & 528 & Clay \\
\hline $0.10-0.15$ & 121 & 11 & 110 & 340 & 539 & Clay \\
\hline $0.15-0.20$ & 120 & 11 & 109 & 334 & 546 & Clay \\
\hline $0.20-0.25$ & 118 & 10 & 108 & 339 & 543 & Clay \\
\hline $0.25-0.30$ & 76 & 7 & 69 & 312 & 612 & Clay \\
\hline
\end{tabular}

With increasing soil bulk density, there was a decrease in macroporosity and microporosity. The increase in total porosity was associated with the increase in macroporosity and microporosity, and increased macroporosity was associated with lower microporosity (Table 2). Soil granulometry was associated with the physical properties of the soil (Table 2), where the increase in the sand content and the decrease in the silt and clay contents were 
related to an increase in bulk density, while a decrease in the sand content and increase in silt and clay correlated with increase in total porosity and microporosity.

Table 2. Pearson correlation between the physical properties of the soil, considering all data from Ultisols and Oxisols.

\begin{tabular}{ccccccccc}
\hline & TP & Macro & Micro & TS & CS & FS & Silt & Clay \\
\hline BD & $-0.86^{* *}$ & $-0.55^{* *}$ & $-0.55^{* *}$ & $0.51^{* *}$ & $0.55^{* *}$ & $0.38^{* *}$ & $-0.17^{*}$ & $-0.52^{* *}$ \\
TP & & $0.38^{* *}$ & $0.81^{* *}$ & $-0.73^{* *}$ & $-0.80^{* *}$ & $-0.55^{* *}$ & $0.24^{* *}$ & $0.75^{* *}$ \\
Macro & & & $-0.22^{*}$ & $0.18^{*}$ & $0.06 \mathrm{~ns}$ & $0.23^{*}$ & $-0.03 \mathrm{~ns}$ & $-0.20^{*}$ \\
Micro & & & & $-0.89^{* *}$ & $-0.88^{* *}$ & $-0.73^{* *}$ & $0.27^{* *}$ & $0.92^{* *}$ \\
\hline
\end{tabular}

Sample size: 126 observations (21 managements/tillage for the five soils $\mathrm{x}$ six soil layers). BD: bulk density; TP: total porosity; Macro: macroporosity; Micro: microporosity; TS: total sand; CS: coarse sand; FS: fine sand. ns: no significative; ${ }^{* *}$ significative at $1 \% ;{ }^{*}$ significative at $5 \%$.

A macroporosity value $<0.10 \mathrm{~m}^{3} \mathrm{~m}^{-3}$ is considered by several authors to be critical for plant growth $[79,80]$. Thus, from the regression analysis between bulk density and macroporosity, it is possible to define the bulk density corresponding to this macroporosity value, which indicates the critical bulk density for soil aeration $\left(\mathrm{BD}_{\text {macro }}\right)$. For the Argissolo Vermelho Distrófico arênico (Ultisol), of the textural class sandy loam, the $\mathrm{BD}_{\text {macro }}=1.66 \mathrm{Mg} \mathrm{m}^{-3}$; for the Argissolo Vermelho Distrófico latossólico (Ultisol), of the textural class loam and clay loam, the $\mathrm{BD}_{\text {macro }}=1.52 \mathrm{Mg} \mathrm{m}^{-3}$; and for the Argissolo Vermelho-Amarelo Alumínico típico (Ultisol), of the textural class silty clay loam and silty clay, the $\mathrm{BD}_{\text {macro }}=1.32 \mathrm{Mg} \mathrm{m}^{-3}$, which was similar to the value for the Latossolo Vermelho Distrófico típico (Oxisol) $\left(\mathrm{BD}_{\text {macro }}=1.33 \mathrm{Mg} \mathrm{m}^{-3}\right)$ and Latossolo Vermelho Aluminoférrico típico (Oxisol) $\left(\mathrm{BD}_{\text {macro }}=1.36 \mathrm{Mg} \mathrm{m}^{-3}\right)$, both of the clay textural class (Table 3$)$.

Table 3. Equations obtained by the relationship between macroporosity (macro) and bulk density (BD) for each soil class, and critical bulk density ( $\left.\mathrm{BD}_{\text {macro }}\right)$ corresponding to a macroporosity of $0.10 \mathrm{~m}^{3} \mathrm{~m}^{-3}$.

\begin{tabular}{cccccc}
\hline Soil & Equation & $\mathbf{R}^{\mathbf{2}}$ & $\mathbf{R M S E}$ & $\mathbf{B D}_{\text {macro, }}$ Mg $\mathbf{~}^{-\mathbf{3}}$ & Textural class \\
\hline AVDA & Macro $=0.47146-0.22396 \mathrm{BD}$ & $0.50^{* *}$ & 0.02509 & 1.66 & Sandy loam \\
AVDL & Macro $=0.59070-0.32295 \mathrm{BD}$ & $0.63^{* *}$ & 0.02607 & 1.52 & Loam and clay loam \\
AVAAT & Macro $=0.51598-0.31617 \mathrm{BD}$ & $0.64^{* *}$ & 0.02407 & 1.32 & Silty clay loam and \\
LVDT & Macro $=0.52469-0.31983 \mathrm{BD}$ & $0.84^{* *}$ & 0.01648 & 1.33 & silty clay \\
LVAT & Macro $=0.57691-0.35060 \mathrm{BD}$ & $0.70^{* *}$ & 0.03108 & 1.36 & Clay \\
\hline
\end{tabular}

Sample size: 126 observations (21 managements/tillage for the five soils $\mathrm{x}$ six soil layers). AVDA: Argissolo Vermelho Distrófico arênico (Ultisol); AVDL: Argissolo Vermelho Distrófico latossólico (Ultisol); AVAAT: Argissolo Vermelho-Amarelo Alumínico típico (Ultisol); LVDT: Latossolo Vermelho Distrófico típico (Oxisol); LVAT: Latossolo Vermelho Aluminoférrico típico (Oxisol). RMSE: root mean squared error. ${ }^{* *}$ significative at $1 \%$.

From the $\mathrm{BD}_{\text {macro }}$ values and the textural class of the soils, the values were inserted into the textural triangle (Figure 2).

The $\mathrm{BD}_{\text {macro }}$ values (Table 3, Figure 2) are similar to those presented by Reichert et al. [61], who obtained critical bulk density values based on the least-limiting water range, and lower than those calculated from the equation (BDrest $=-0.00071$ clay +1.86180 ) provided by Reichert et al. [19], obtained from critical bulk density values based on the root growth restriction of annual crops. Calculating bulk density from the equation proposed by Reichert et al. [19], the critical bulk density ranges for the soils in this study are: AVDA $=1.8 \mathrm{Mg} \mathrm{m}^{-3}, \mathrm{AVDL}=1.6$ to $1.7 \mathrm{Mg} \mathrm{m}^{-3}, \mathrm{AVAAT}=1.5$ to $1.6 \mathrm{Mg} \mathrm{m}^{-3}, \mathrm{LVDT}=1.5$ to $1.6 \mathrm{Mg} \mathrm{m}^{-3}$, and LVAT $=1.4$ to $1.5 \mathrm{Mg} \mathrm{m}^{-3}$. On the other hand, from the values presented by Reichert et al. [61], the bulk density ranges for some soils in this study are: AVDA $=1.7$ to $1.8 \mathrm{Mg} \mathrm{m}^{-3}, \mathrm{AVDL}=1.4$ to $1.5 \mathrm{Mg} \mathrm{m}^{-3}$, AVAAT = not rated by Reichert et al. [61], and LVDT and LVAT $=1.3$ to $1.4 \mathrm{Mg} \mathrm{m}^{-3}$. 


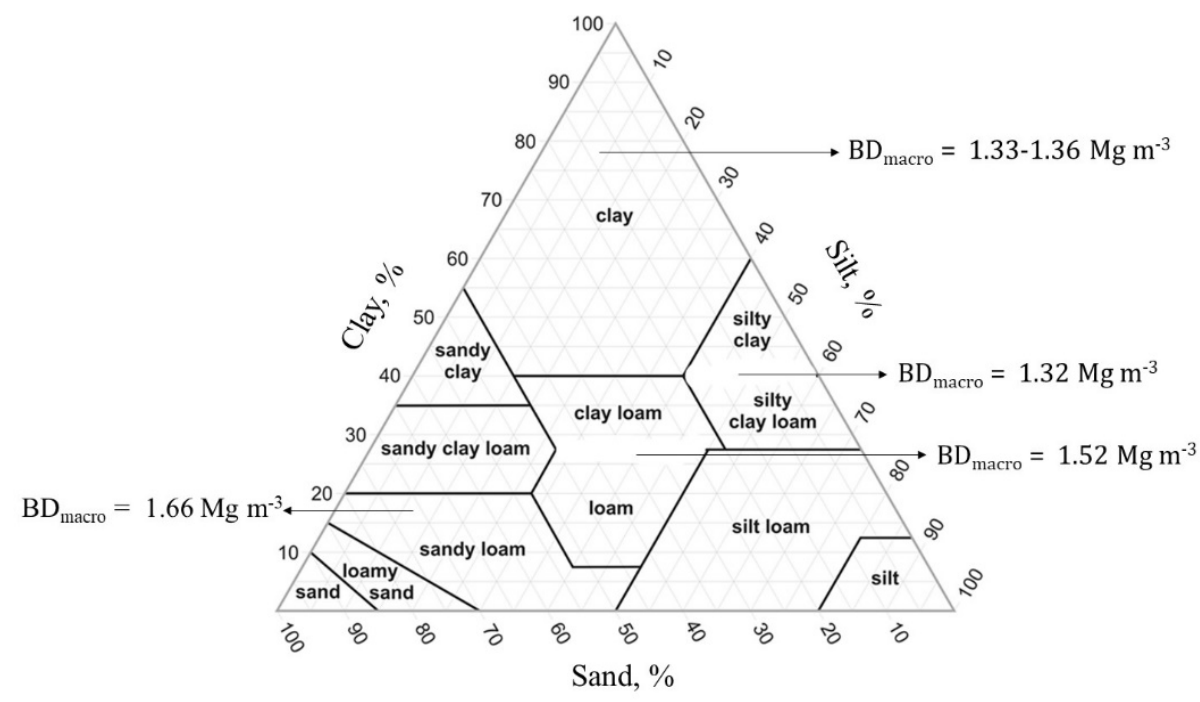

Figure 2. Textural triangle with values of $\mathrm{BD}_{\text {macro }}$ (critical bulk density corresponding to macroporosity of $0.10 \mathrm{~m}^{3} \mathrm{~m}^{-3}$ ).

In an experiment in pots, using Oxisols with different clay contents, a 50\% reduction in soybean root growth occurred for bulk densities of $1.82,1.75,1.51$, and $1.45 \mathrm{Mg} \mathrm{m}^{-3}$, respectively, for a soil sandy loam, sandy clay loam, clay, and very clay [4]. In another study, also in the laboratory, the diameter of the corn stalk was reduced when the surface layer of the Latossolo Vermelho-Amarelo Distrófico, with texture class sandy clay, reached a bulk density of $1.7 \mathrm{Mg} \mathrm{m}^{-3}$, while in the subsurface layer the reduction occurs in the bulk density of $1.5 \mathrm{Mg} \mathrm{m}^{-3}$, a problem that can cause plant lodging [62]. In a field experiment in an Argissolo Vermelho with $150 \mathrm{~g} \mathrm{~kg}^{-1}$ clay and $730 \mathrm{~g} \mathrm{~kg}^{-1}$ sand in horizon A, cover crop roots grew normally to the bulk density of $1.75 \mathrm{Mg} \mathrm{m}^{-3}$, while in the range of 1.75 to $1.85 \mathrm{Mg} \mathrm{m}^{-3}$ there was restriction with the deformation of the roots [36]. Generally, values from the literature are higher than that presented in Figure 2.

All managements of Argissolo Vermelho Distrófico arênico had a bulk density lower than the critical value $\left(\mathrm{BD}_{\text {macro }}=1.66 \mathrm{Mg} \mathrm{m}^{-3}\right)$ or slightly higher in the 0.20 to $0.25 \mathrm{~m}$ layer, such as the Chisel management, while the macroporosity was lower than the critical value $\left(0.10 \mathrm{~m}^{3} \mathrm{~m}^{-3}\right)$ only for the NTC management and below the $0.10 \mathrm{~m}$ layer (Figure 3$)$. With no physical restrictions on the topsoil, the root system of the soybean (and edible black bean for Chisel management) reached $0.15 \mathrm{~m}$ in depth.

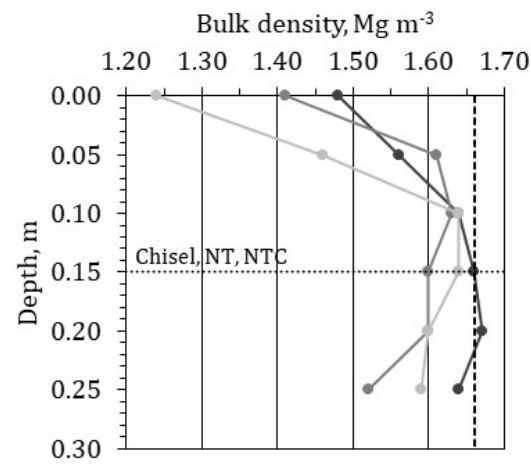

(a)

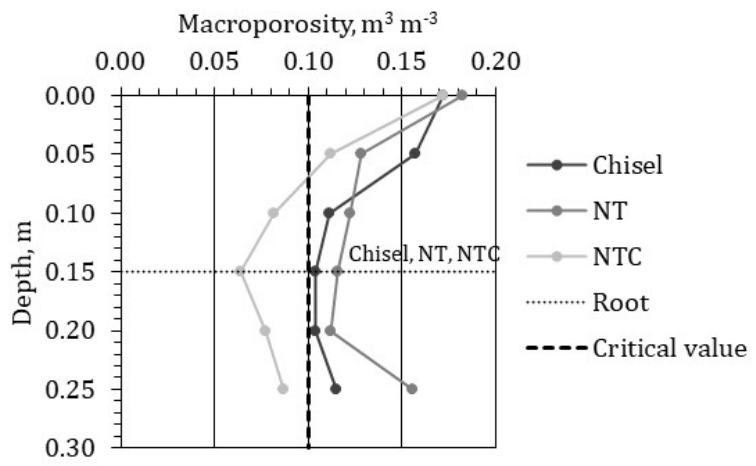

(b)

Figure 3. (a) Bulk density and (b) macroporosity average values, root system depth, bulk density $\left(\mathrm{BD}_{\text {macro }}=1.66 \mathrm{Mg} \mathrm{m}^{-3}\right)$, and macroporosity $\left(0.10 \mathrm{~m}^{3} \mathrm{~m}^{-3}\right)$ critical values for the Argissolo Vermelho Distrófico arênico (Ultisol) and their respective managements under study. 
All management systems for Argissolo Vermelho Distrófico latossólico (Figure 4), Argissolo Vermelho-Amarelo Alumínico típico (Figure 5), and Latossolo Vermelho Distrófico típico (Figure 6) presented bulk densities higher than the critical $\left(\mathrm{BD}_{\text {macro }}=1.52 \mathrm{Mg} \mathrm{m}^{-3}\right.$, $\mathrm{BD}_{\text {macro }}=1.32 \mathrm{Mg} \mathrm{m}^{-3}$, and $\mathrm{BD}_{\text {macro }}=1.33 \mathrm{Mg} \mathrm{m}^{-3}$, respectively) and a macroporosity smaller than $0.10 \mathrm{~m}^{3} \mathrm{~m}^{-3}$. This occurred especially below the $0.05 \mathrm{~m}$ layer, limiting root growth to the layer and from 0.08 to $0.10 \mathrm{~m}$ for the Argissolo Vermelho Distrófico latossólico, and $0.10 \mathrm{~m}$ for the Argissolo Vermelho-Amarelo Alumínico típico, except the NT 2 that, even with the physical limitations of the soil, reached $0.16 \mathrm{~m}$ in depth.

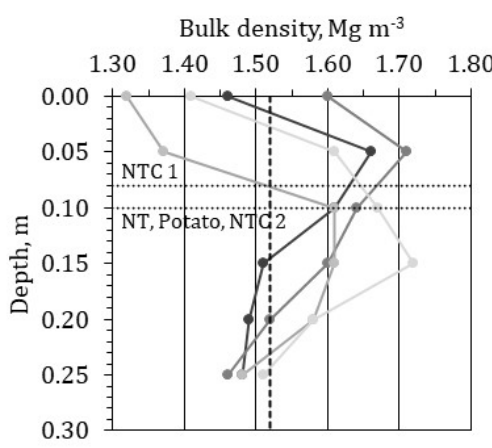

(a)

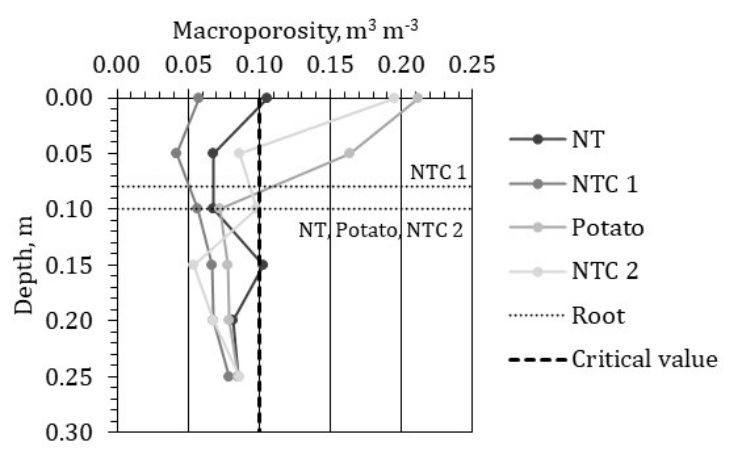

(b)

Figure 4. (a) Bulk density and (b) macroporosity average values, root system depth, bulk density $\left(B_{\text {macro }}=1.52 \mathrm{Mg} \mathrm{m}^{-3}\right)$, and macroporosity $\left(0.10 \mathrm{~m}^{3} \mathrm{~m}^{-3}\right)$ critical values for the Argissolo Vermelho Distrófico latossólico (Ultisol) and their respective managements under study.

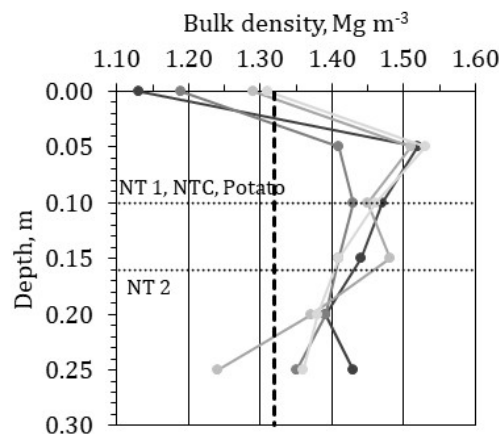

(a)

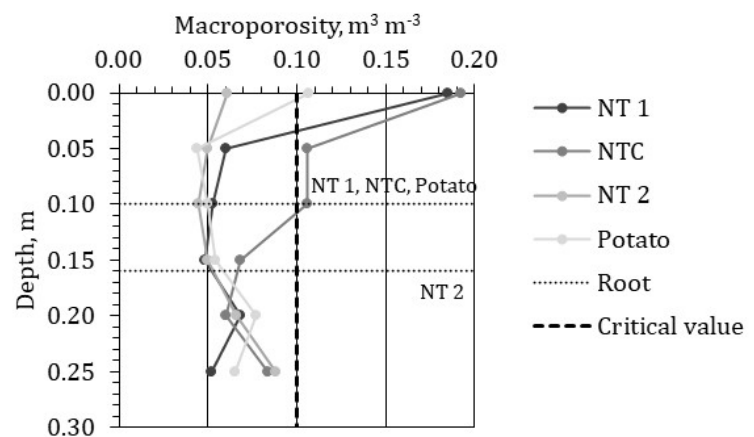

(b)

Figure 5. (a) Bulk density and (b) macroporosity average values, root system depth, bulk density $\left(\mathrm{BD}_{\text {macro }}=1.32 \mathrm{Mg} \mathrm{m}^{-3}\right)$, and macroporosity $\left(0.10 \mathrm{~m}^{3} \mathrm{~m}^{-3}\right)$ critical values for the Argissolo VermelhoAmarelo Alumínico típico (Ultisol) and their respective managements under study.

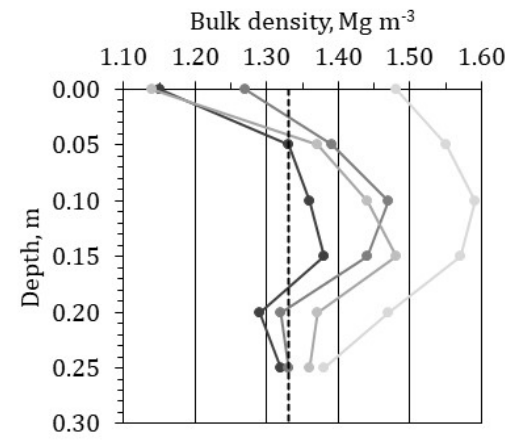

(a)

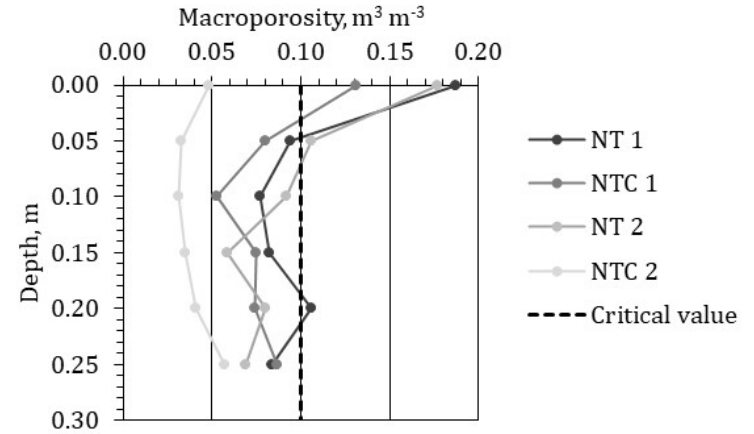

(b)

Figure 6. (a) Bulk density and (b) macroporosity average values, root system depth, bulk density $\left(\mathrm{BD}_{\text {macro }}=1.33 \mathrm{Mg} \mathrm{m}^{-3}\right)$, and macroporosity $\left(0.10 \mathrm{~m}^{3} \mathrm{~m}^{-3}\right)$ critical values for the Latossolo Vermelho Distrófico típico (Oxisol) and their respective managements under study. 
In the Latossolo Vermelho Aluminoférrico típico (Figure 7), soil bulk density $\left(\mathrm{BD}_{\text {macro }}=1.36 \mathrm{Mg} \mathrm{m}^{-3}\right)$ and macroporosity $\left(0.10 \mathrm{~m}^{3} \mathrm{~m}^{-3}\right)$ critical values limited root growth, particularly in the NT 2. However, NT 1 and Pasture are noteworthy, in which, even with physical limitations from the $0.05 \mathrm{~m}$ layer onwards, the roots reached, respectively, 0.20 and $0.30 \mathrm{~m}$ in depth. To penetrate more resistant soil layers, the root increases its diameter, as long as this resistance is not so high as to bend or deflect the root, and thus they find paths of lesser resistance. On the other hand, in regions of the soil where resistance is higher and oxygen and nutrient availability are deficient, the roots grow less and the plant compensates this by growing more in the less resistant zones [81].

Bulk density, $\mathrm{Mg} \mathrm{m}^{-3}$

$\begin{array}{lllllll}1.00 & 1.10 & 1.20 & 1.30 & 1.40 & 1.50 & 1.60\end{array}$

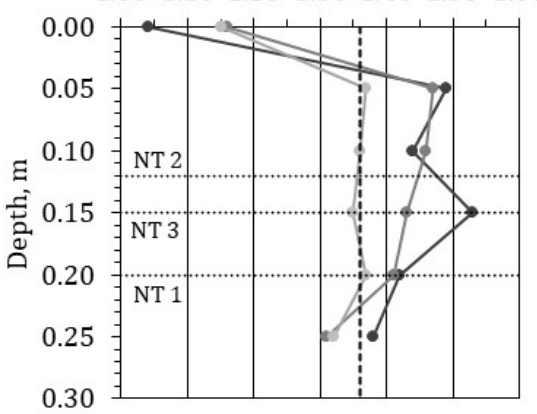

(a)

Bulk density, $\mathrm{Mg} \mathrm{m}^{-3}$

1.001 .101 .201 .301 .401 .501 .60

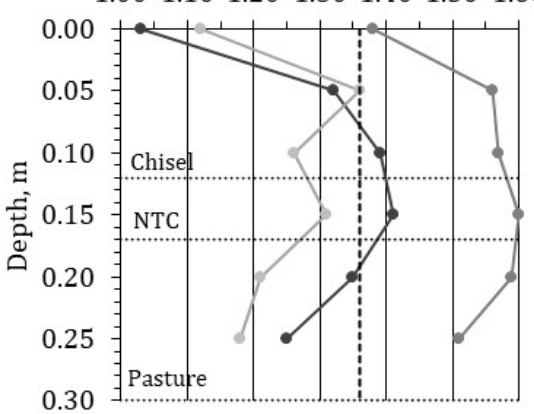

(c)

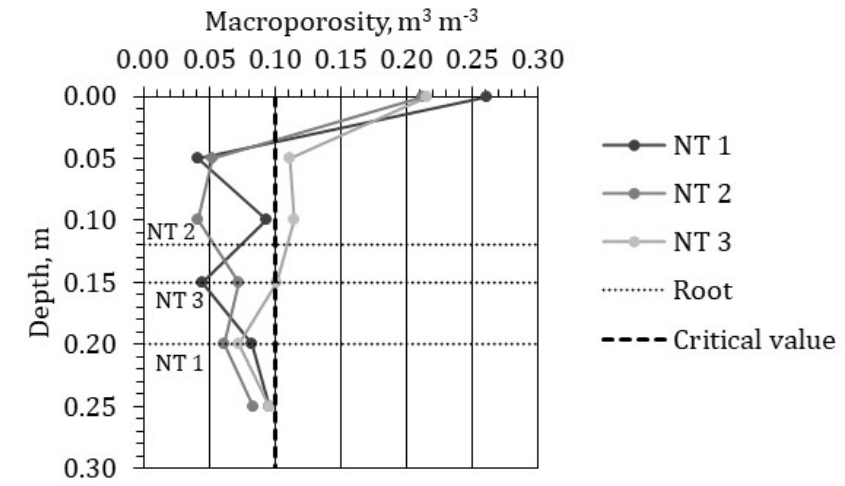

(b)

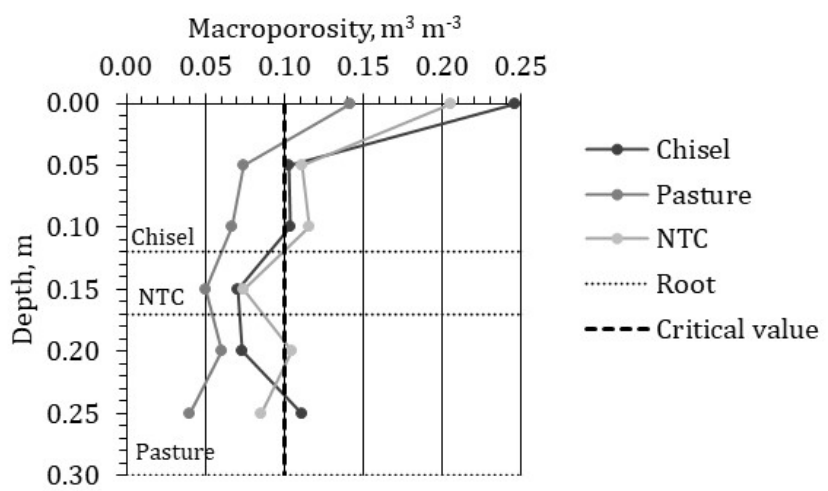

(d)

Figure 7. (a,c) Bulk density and (b,d) macroporosity average values, root system depth, bulk density $\left(\operatorname{BD}_{\text {macro }}=1.36 \mathrm{Mg} \mathrm{m}^{-3}\right)$, and macroporosity $\left(0.10 \mathrm{~m}^{3} \mathrm{~m}^{-3}\right)$ critical values for the Latossolo Vermelho Aluminoférrico típico (Oxisol) and their respective managements under study.

Generally, the results indicate that the critical values of bulk density and macroporosity limit root growth for all soils in our study.

Assessing the spatial variability of penetration resistance in an experimental area of 0.2 ha with different sampling grids in an Oxisol in the south-central region of Paraná, the soil layer between 0.05 and $0.20 \mathrm{~m}$ was the one with the highest resistance values [58]. In a laboratory study on the influence of soil compaction on maize crops, Carneiro et al. [68] found that leaf mass was reduced regardless of the depth of the compacted layer; however, when it occurs in the surface layer, the problem is exacerbated due to the low availability of water and nutrients for the establishment of the plant, which requires a large amount of energy to develop its root system.

Using microporosity as a reference, obtained by applying a tension of $6 \mathrm{kPa}$, it is noted that the volumetric moisture at the time of assessing the soil mechanical resistance to penetration, in general, presented values lower or close to those obtained at a tension of $6 \mathrm{kPa}$ (Figure 8). Knowledge of moisture and other physical properties when assessing penetration resistance is important, as soil mechanical resistance to penetration is related 
to soil moisture, bulk density, and texture [67-69]. For example, there was an increase in penetration resistance as the soil reduced moisture, and small differences in soil bulk density affected the penetration resistance as a function of moisture in different ways in a Latossolo Vermelho-Amarelo with $0.366 \mathrm{~kg} \mathrm{~kg}^{-1}$ clay [68].

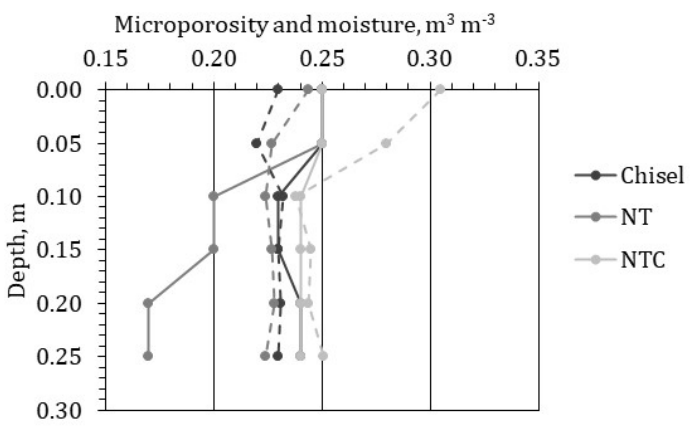

(a)

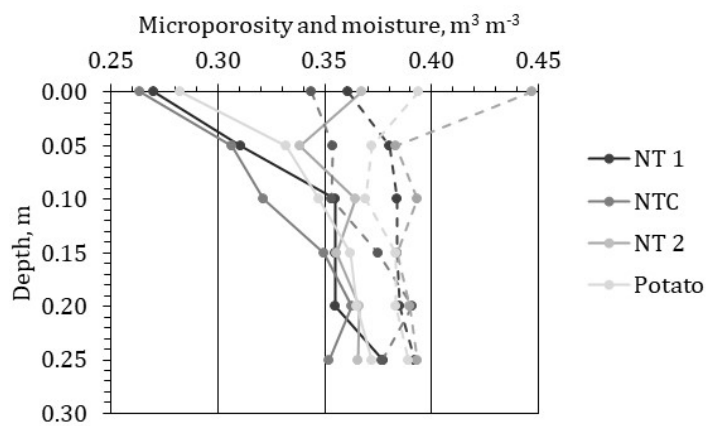

(c)

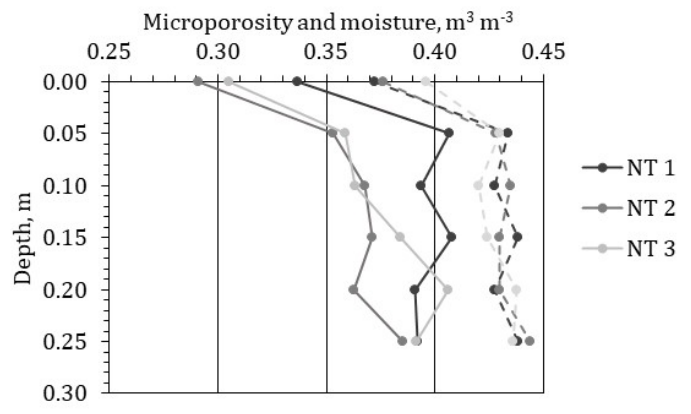

(e)

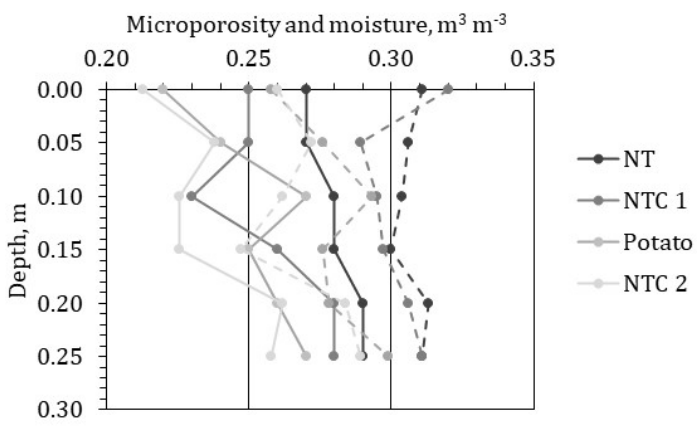

(b)

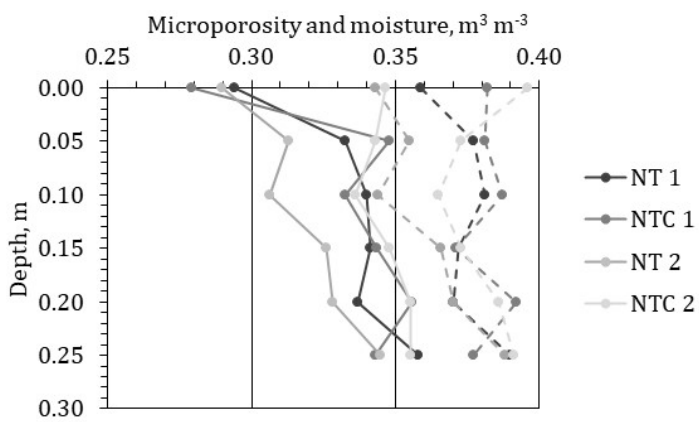

(d)

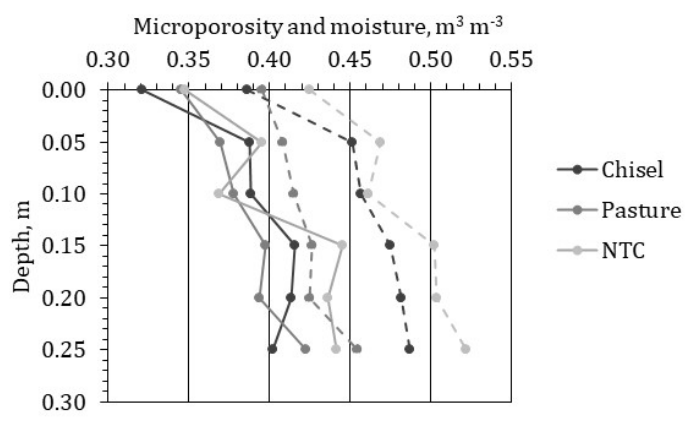

(f)

Figure 8. Average values of microporosity (dashed line) and volumetric moisture (solid line) at the time of evaluating the mechanical resistance of the soil to penetration of the (a) Argissolo Vermelho Distrófico arênico (Ultisol), (b) Argissolo Vermelho Distrófico latossólico (Ultisol), (c) Argissolo Vermelho-Amarelo Alumínico típico (Ultisol), (d) Latossolo Vermelho Distrófico típico (Oxisol), $(\mathbf{e}, \mathbf{f})$ Latossolo Vermelho Aluminoférrico típico (Oxisol), and respective managements.

Under high bulk density values, the increase in soil water content reduced penetration resistance, allowing soybean root growth to occur without restrictions in Oxisols with a clay content varying between 195.1 and $730.3 \mathrm{~g} \mathrm{~kg}^{-1}$ [4]. The authors found that, regardless of the soil textural class, the values of 2 and $3 \mathrm{MPa}$, considered limiting for root growth, had a small effect on soybean root growth when soil moisture was maintained at field capacity.

For the soils and managements under study, the soil's mechanical resistance to penetration presents variability in the profile, generally with lower values on the surface and increasing in depth (Figures 9-12). In an Argissolo Amarelo, the increase in resistance to penetration in depth was associated with the natural accommodation of clays, and the decrease in organic matter and microbiological activity at deeper layers in the soil profile [82]. 

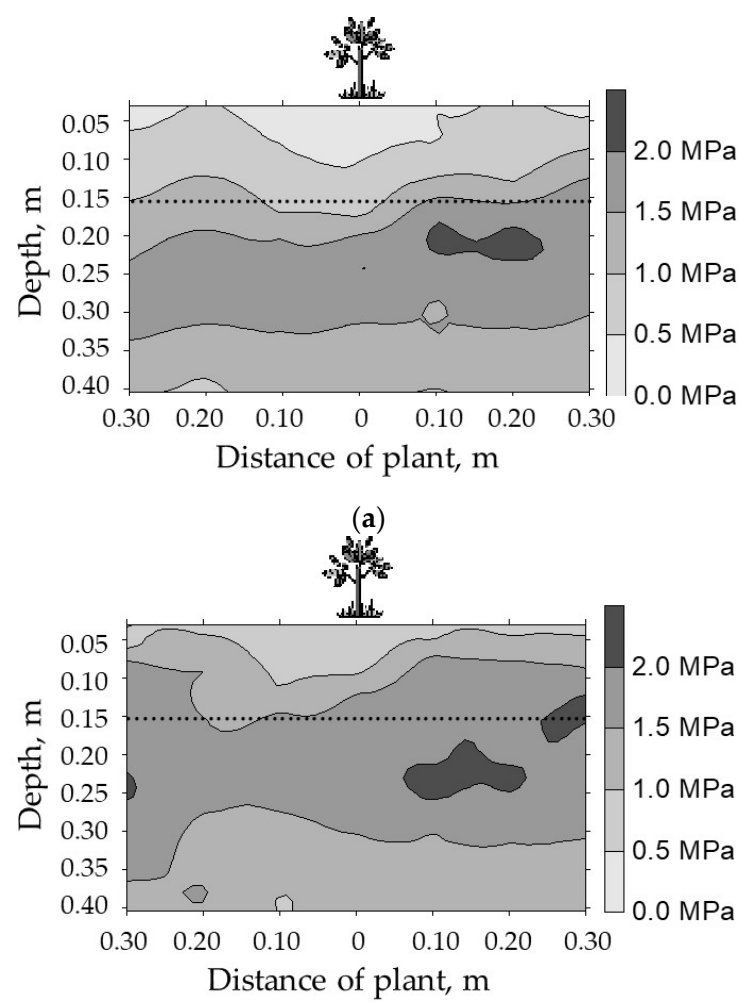

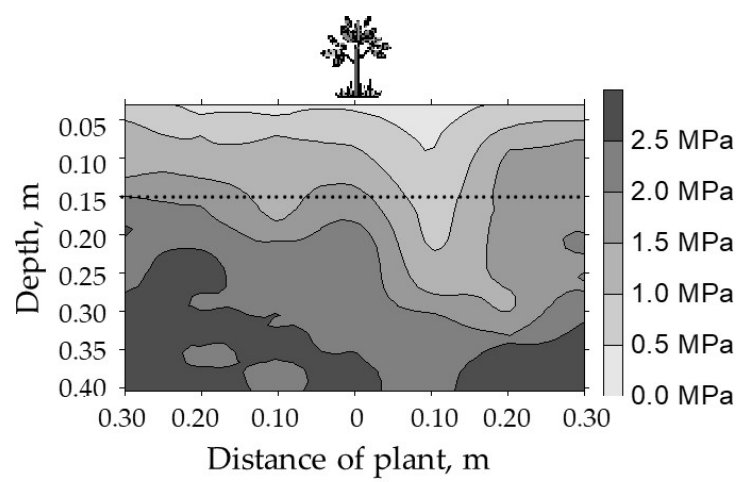

(b)

(c)

Figure 9. Profile of mechanical resistance to penetration of Argissolo Vermelho Distrófico arênico (Ultisol) in the managements (a) Chisel, (b) NT, and (c) NTC. $\cdots \cdots$ root system depth.
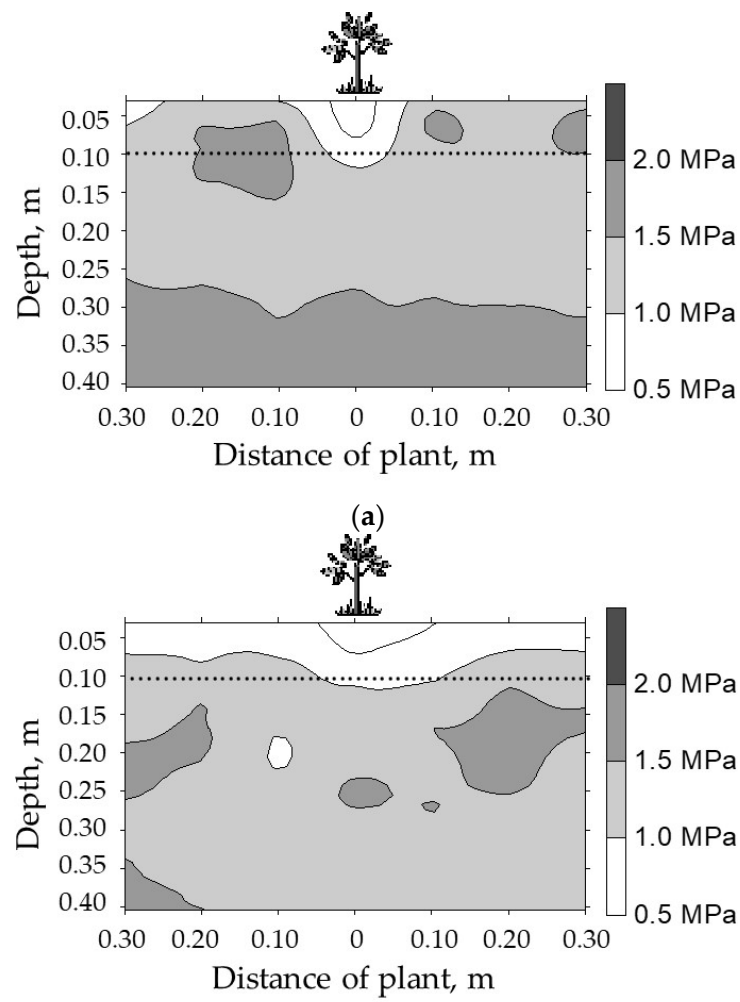

(c)
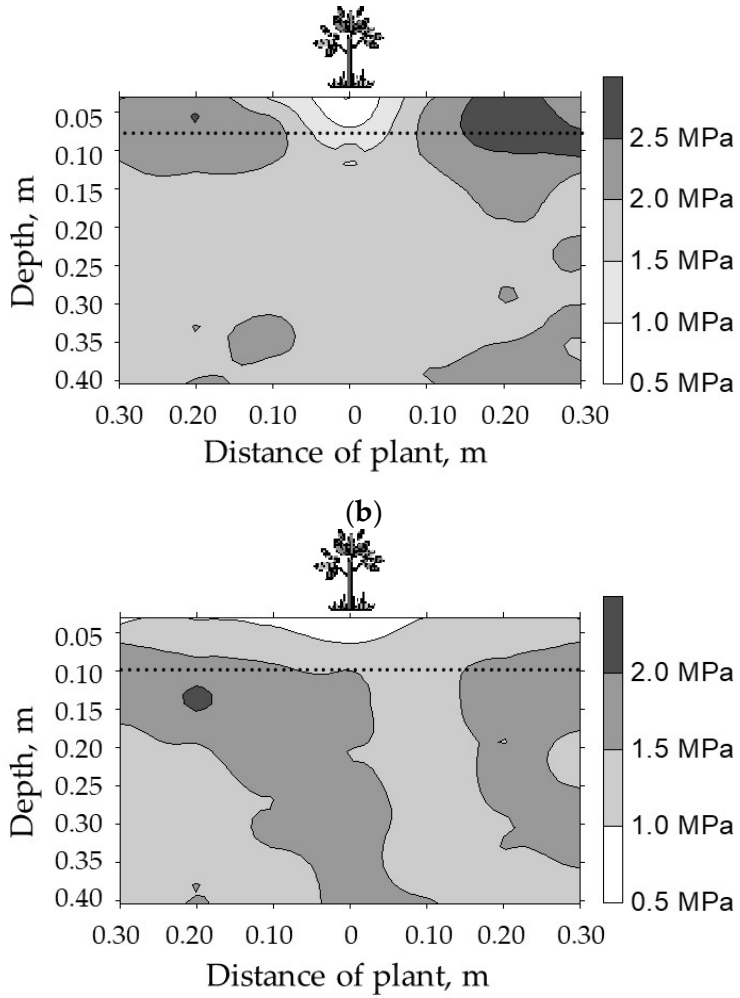

(d)

Figure 10. Profile of mechanical resistance to penetration of Argissolo Vermelho Distrófico latossólico

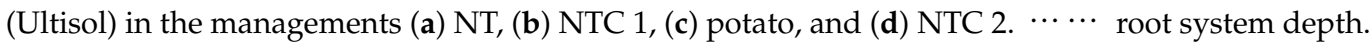




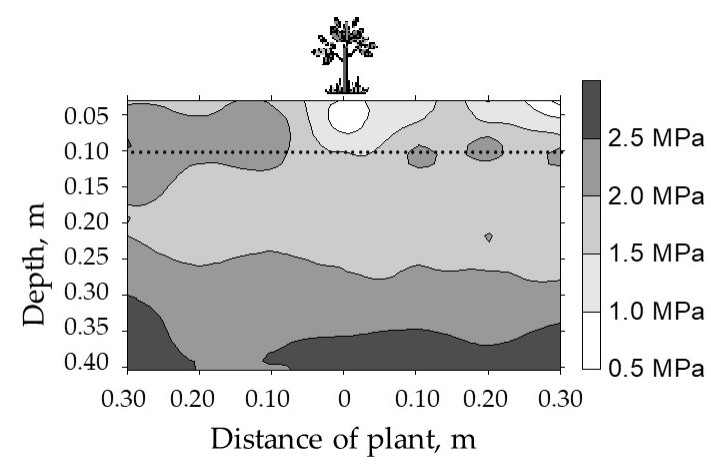

(a)

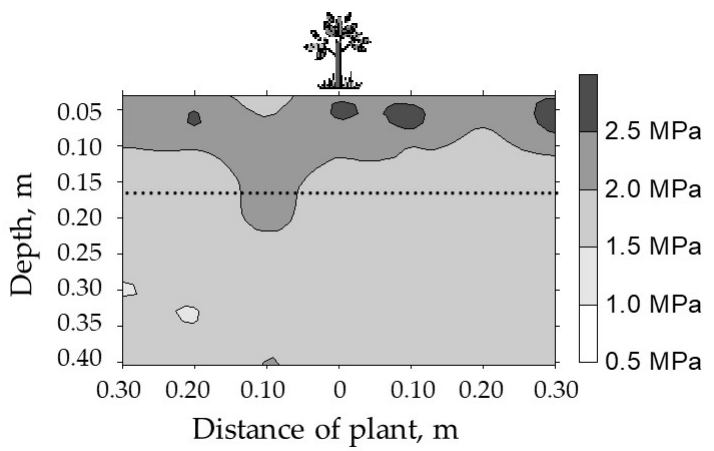

(c)

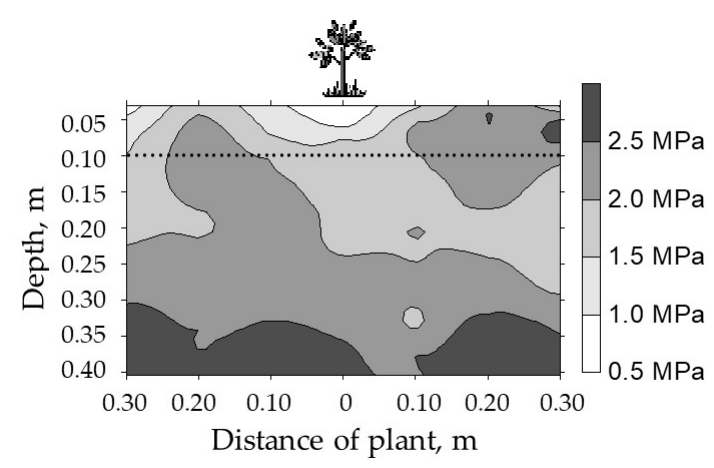

(b)

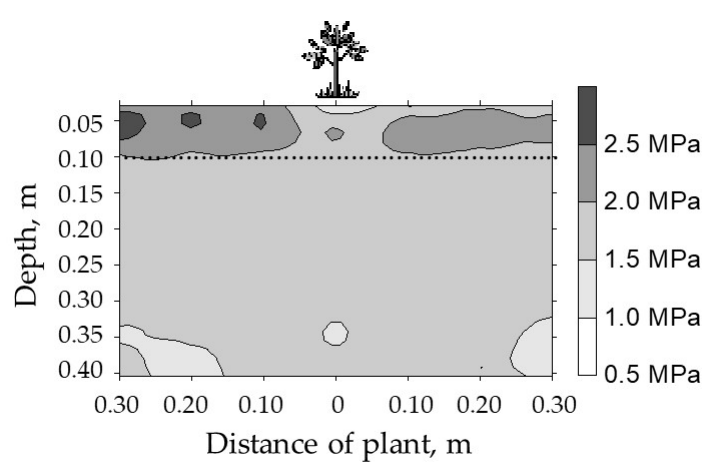

(d)

Figure 11. Profile of mechanical resistance to penetration of Argissolo Vermelho-Amarelo Alumínico típico (Ultisol) in the managements (a) NT 1, (b) NTC, (c) NT 2, and (d) potato. $\cdots \cdots$ root system depth.
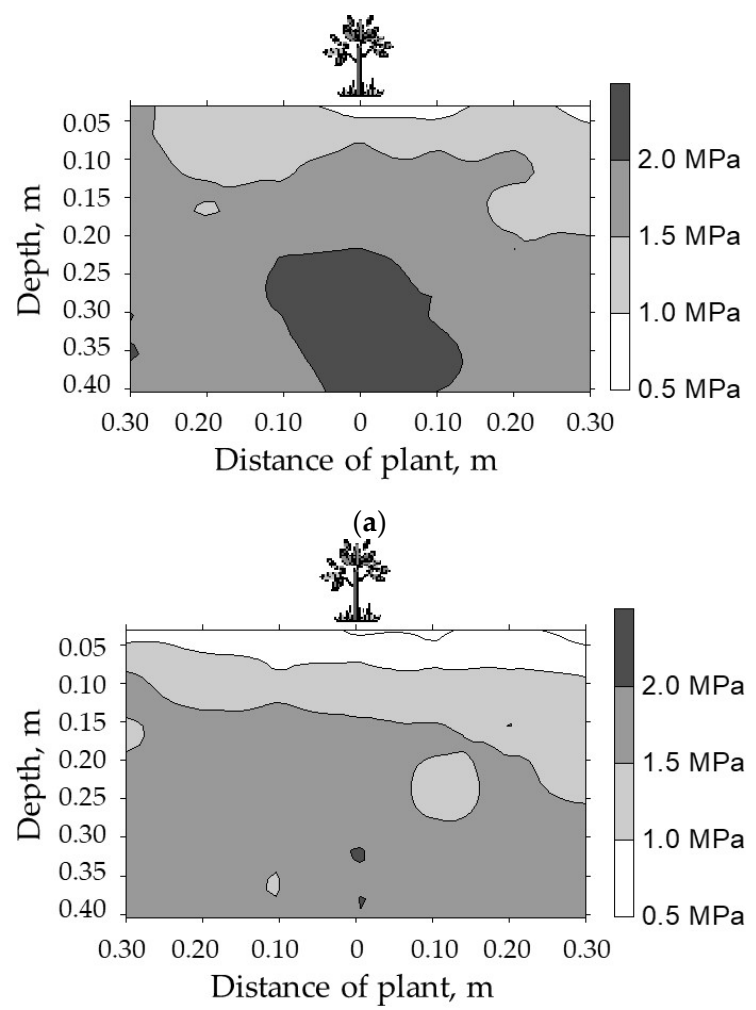

(c)
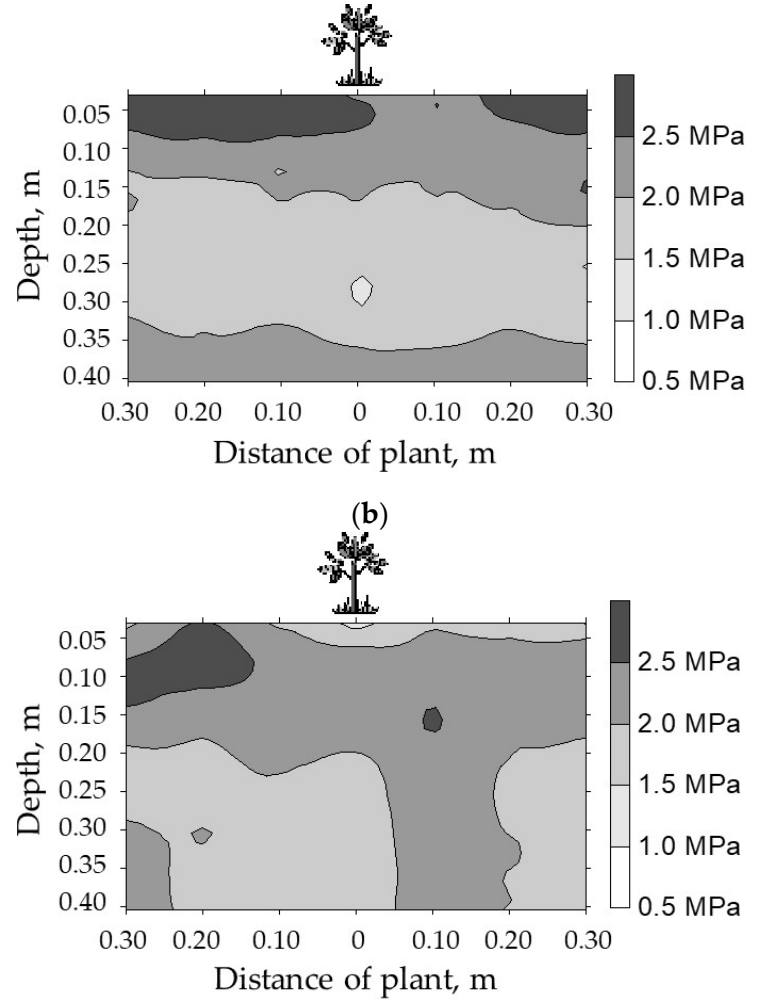

(d)

Figure 12. Profile of mechanical resistance to penetration of Latossolo Vermelho Distrófico típico (Oxisol) in the managements (a) NT 1, (b) NTC 1, (c) NT 2, and (d) NTC 2. The depth of the root system was not evaluated. 
In general, soil layers with a resistance of $<2 \mathrm{MPa}$ may have limited root system growth, with 1.5 to $2 \mathrm{MPa}$ for the Argissolo Vermelho Distrófico arênico and Argissolo Vermelho-Amarelo Alumínico, 1 to $1.5 \mathrm{MPa}$ for the Argissolo Vermelho Distrófico latossólico (Figures 9-11), and between 2 and 3.5 MPa for the Latossolo Vermelho Aluminoférrico típico (Figure 13). In the Latossolo Vermelho Aluminoférrico típico, pasture management demands special attention, because the soybean roots grew up to $0.30 \mathrm{~m}$, even passing through the most resistant layer, which may be associated with the presence of biopores, allowing for preferential root penetration.

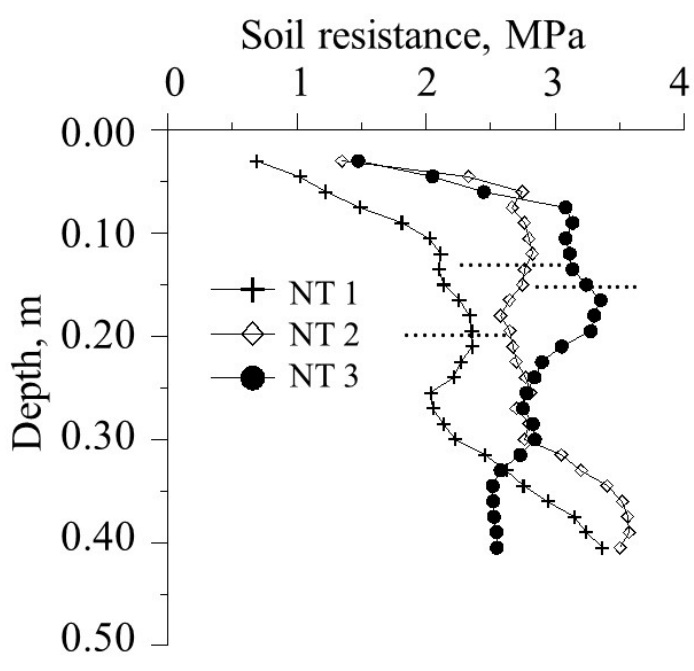

(a)

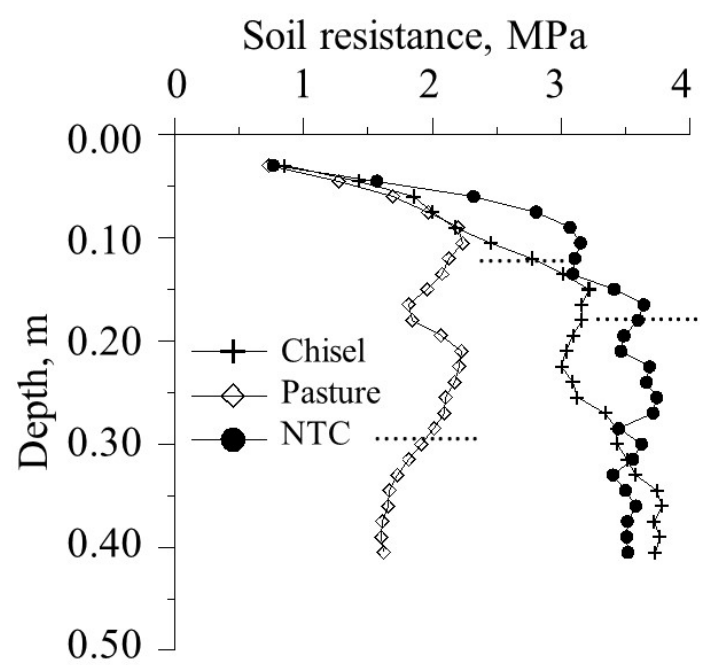

(b)

Figure 13. Mechanical resistance to penetration of Latossolo Vermelho Aluminoférrico típico (Oxisol) in the managements (a) NT 1, NT 2, and NT 3; (b) Chisel, Pasture, and NTC. $\cdots \cdots$ root system depth.

Although horizontal layers with similar resistance occur, in some cases there is discontinuity of these layers with zones of smaller resistance, which allows the roots to use these zones of lesser resistance to deepen the profile. According to Queiroz-Voltan et al. [83], as compaction does not present itself as a continuous mass in the field, the roots search for free spaces in the soil to develop. From isolines maps of penetration resistance, it is possible to identify the depth of action of agricultural implements and compacted soil layers [82]. Even with the increase in bulk density and soil resistance to penetration and the decrease of macroporosity, the area and root length of corn were not affected in the Latossolo Vermelho Distrófico and a Latossolo Vermelho eutroférrico [84]. According to the authors, root growth can be inhibited with penetration resistance values below $1 \mathrm{MPa}$ in dry soils; however, with enough moisture, growth can occur with a resistance to penetration ranging from 4 to $5 \mathrm{MPa}$.

Between the rows of the crop, in general, there was greater resistance to penetration, since the cutting disc or seeder rod ruptures the layer of greater resistance in the row (Figures 9-12), allowing root growth in the first centimeters of the soil (Figures 9-11). The furrower mechanisms may mobilize $30 \%$ of the soil surface area to a depth of $0.05 \mathrm{~cm}$ in winter crops with $0.17 \mathrm{~m}$ spacings [38]. Therefore, when the sowing for soybeans is added in succession, in a short time the entire surface layer is mobilized. Unger and Kaspar [85] state that soils are not uniformly compacted by machine traffic. Because the traffic direction for many field operations is parallel to the planting row, traffic tends to be concentrated in the rows, and some rows are compacted while others are not. As a result, traffic can cause significant differences in soil physical conditions between trafficked and non-trafficked rows, as studied in detail by Reichert et al. [86] for various soil properties.

The depth reached by the root system (soybean and edible black bean in the Argissolo Vermelho Distrófico arênico-Chisel) in the soils and managements under study was 
affected by soil properties, such as bulk density and soil resistance to penetration. Reichert et al. [61] comment that the root system perceives and integrates all soil conditions in space and time, similarly to the aerial part of plants, which is exposed to constant changes in the environment, clearly indicating that stresses in the aerial part and root system are equally important.

Crop yield is a function of several factors, such as physical, chemical, and biological soil properties, management given to the crop, in addition to climatic factors. Some soils may have unsuitable conditions, but proper climatic and rainfall conditions can minimize these effects. In the constant climatic adversities, a soil in a good condition allows the farmer to plan, as variations in yield are less fluctuating. For example, the effects of compaction in a clayey soil can be mitigated over time as a function of biopores formed by predecessor crops, especially cover crops, combined with the natural wetting and drying cycles of the soil [71]. Similarly, in a sandy loam soil, the use of cover crops reduced soil resistance to penetration by $25 \%$ compared to the value of $2 \mathrm{MPa}$ after two crop rotation cycles, and $32 \%$ after three cycles [72]. These authors also verified that plant roots need approximately 4 to 6 years to decompose and produce biopores through the compacted soil layer.

To facilitate decision making on soil management considering the critical bulk density $\left(\mathrm{BD}_{\text {macro }}\right)$ corresponding to a macroporosity of $0.10 \mathrm{~m}^{3} \mathrm{~m}^{-3}$, the relative soil bulk density was calculated through the relationship between the current bulk density of the soil and the $\mathrm{BD}_{\text {macro }}$ for each soil class (Table 4).

Table 4. Average values of relative bulk density for the different soils and their respective managements under study.

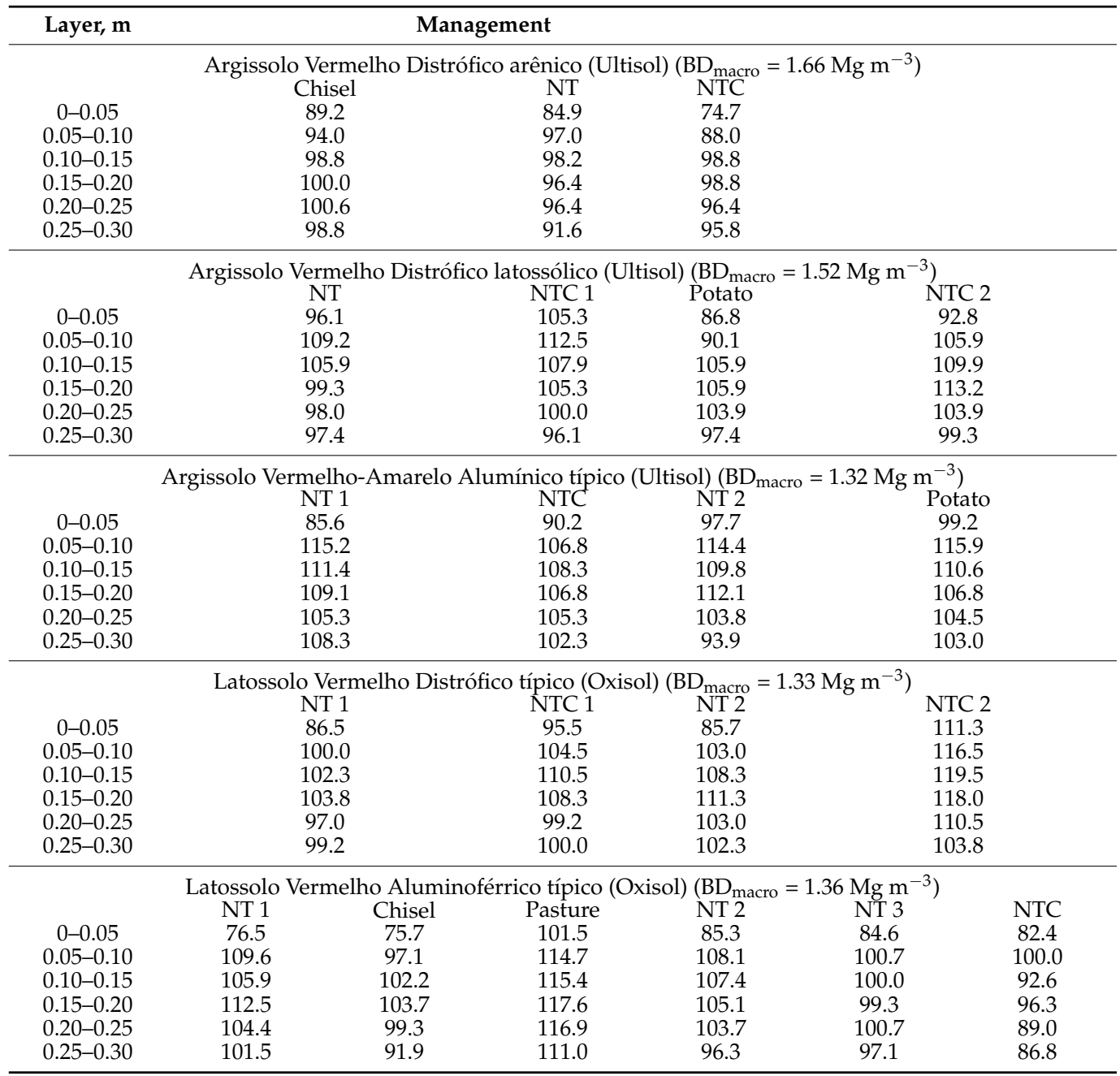


These relative bulk density values represent how close the actual soil bulk density is in relation to the critical bulk density. For example, relative bulk density values greater than $100 \%$ indicate that the soil bulk density is greater than critical, while values smaller than $100 \%$ mean that the bulk density is smaller than critical. Furthermore, it is possible to define, according to the percentage of relative bulk density, some action that should be taken to prevent the bulk density from being close to the critical one, namely mechanical soil management such as chiseling or vegetative management through cover crops with a root system that improves the soil physics properties. Bulk density values greater than $85 \%$ could thus be defined as an alert for decision making in relation to soil management.

\section{Conclusions}

From the evaluation of some physical properties associated with the compaction of Ultisols and Oxisols subjected to different management systems, it is concluded that with the increasing of soil bulk density there is a decrease in its macroporosity, and the variation in the content of sand, silt, and clay of soil is related to bulk density and porosity.

From a regression analysis between bulk density and macroporosity for each soil class, the bulk density ( $\mathrm{BD}_{\text {macro }}$ ) corresponding to a macroporosity of $0.10 \mathrm{~m}^{3} \mathrm{~m}^{-3}$, considered critical for plant growth, was defined, according to the textural class, as: sandy loam$\mathrm{BD}_{\text {macro }}=1.66 \mathrm{Mg} \mathrm{m}^{-3}$; loam and clay loam $-\mathrm{BD}_{\text {macro }}=1.52 \mathrm{Mg} \mathrm{m}^{-3}$; silty clay loam and silty clay- $\mathrm{BD}_{\text {macro }}=1.32 \mathrm{Mg} \mathrm{m}^{-3}$; and clay- $\mathrm{BD}_{\text {macro }}=1.33$ to $1.36 \mathrm{Mg} \mathrm{m}^{-3}$.

Soil's mechanical resistance to penetration presents variability in the profile, generally with lower values on the surface and increasing in depth, in response to soil management. Although there are horizontal layers in the soil profile with similar resistance, in some cases there is discontinuity of these layers with zones of smaller resistance, which allows the roots to use these zones to deepen into the profile.

Penetration resistance values that limited the root growth of the soybean and edible black bean (in the Argissolo Vermelho Distrófico arênico-Chisel) were from 1.5 to $2 \mathrm{MPa}$ for the Argissolo Vermelho Distrófico arênico (Ultisol) (of the textural class "sandy loam") and Argissolo Vermelho-Amarelo Alumínico (Ultisol) (of the textural classes "silty clay loam" and "silty clay"), 1 to $1.5 \mathrm{MPa}$ to the Argissolo Vermelho Distrófico latossólico (Ultisol) (of the textural class "loam"), and 2 to $3.5 \mathrm{MPa}$ to the Latossolo Vermelho Aluminoférrico típico (Oxisol) (of the textural class "clay").

Author Contributions: Conceptualization, L.E.A.S.S., D.J.R. and J.M.R.; formal analysis, L.E.A.S.S., D.J.R., M.C.A. and J.M.R.; investigation, L.E.A.S.S. and D.J.R.; methodology, L.E.A.S.S., D.J.R., M.C.A. and J.M.R.; resources, D.J.R. and J.M.R.; writing—original draft, L.E.A.S.S. and D.J.R.; writingreview and editing, M.C.A. and J.M.R. All authors have read and agreed to the published version of the manuscript.

Funding: This research received no external funding.

Institutional Review Board Statement: Not applicable.

Informed Consent Statement: Informed consent was obtained from all subjects involved in the study.

Data Availability Statement: Data available on request from the authors.

Acknowledgments: To the farmers, for their logistical support and for the possibility of using their areas to carry out this work. To CAPES, for granting the scholarship to the first author, and to CNPq, for granting productivity scholarships.

Conflicts of Interest: The authors declare no conflict of interest.

\section{References}

1. Silva, P.L.F. Compactação e seus efeitos sobre o funcionamento do solo e a absorção de nutrientes pelas plantas: Uma revisão bibliográfica. Meio Ambiente 2021, 3, 24-33.

2. Lima, C.L.R.; Reinert, D.J.; Reichert, J.M.; Suzuki, L.E.A.S.; Gubiani, P.I. Qualidade físico-hídrica e rendimento de soja (Glycine max L.) e feijão (Phaseolus vulgaris L.) de um Argissolo Vermelho Distrófico sob diferentes sistemas de manejo. Ciência Rural 2006, 36, 1172-1178. [CrossRef] 
3. Suzuki, L.E.A.S.; Reichert, J.M.; Reinert, D.J. Degree of compactness, soil physical properties and yield of soybean in six soils under no-tillage. Soil Res. 2013, 51, 311-321. [CrossRef]

4. Sato, M.K.; Lima, H.V.; Oliveira, P.D.; Rodrigues, S. Critical soil bulk density for soybean growth in Oxisols. Int. Agrophysics 2015, 29, 441-447. [CrossRef]

5. Cecagno, D.; de Andrade Costa, S.E.V.G.; Anghinoni, I.; Kunrath, T.R.; Martins, A.P.; Reichert, J.M.; Gubiani, P.I.; Balerini, F.; Fink, J.R.; de Faccio Carvalho, P.C. Least limiting water range and soybean yield in a long-term, no-till, integrated crop-livestock system under different grazing intensities. Soil Tillage Res. 2016, 156, 54-62. [CrossRef]

6. $\quad$ Mentges, M.I.; Reichert, J.M.; Rodrigues, M.F.; Awe, G.O.; Mentges, L.R. Capacity and intensity soil aeration properties affected by granulometry, moisture, and structure in no-tillage soils. Geoderma 2016, 263, 47-59. [CrossRef]

7. Reichert, J.M.; Mentges, M.I.; Rodrigues, M.F.; Cavalli, J.P.; Awe, G.O.; Mentges, L.R. Compressibility and elasticity of subtropical no-till soils varying in granulometry organic matter, bulk density and moisture. Catena 2018, 165, 345-357. [CrossRef]

8. Veiga, M.; Reinert, D.J.; Reichert, J.M. Tillage systems and nutrient sources affecting soil cover, temperature and moisture in a clayey oxisol under corn. Rev. Bras. Ciênc. Solo 2010, 34, 2011-2020. [CrossRef]

9. Gubiani, P.I.; Goulart, R.Z.; Reichert, J.M.; Reinert, D.J. Crescimento e produção de milho associados com o intervalo hídrico ótimo. Rev. Bras. Ciênc. Solo 2013, 37, 1502-1511. [CrossRef]

10. Reichert, J.M.; Brandt, A.A.; Rodrigues, M.F.; Reinert, D.J.; Braida, J.A. Load dissipation by corn residue on tilled soil in laboratory and field-wheeling conditions: Lab and field load dissipation by soil surface mulch. J. Sci. Food Agric. 2016, 96, 2705-2714. [CrossRef]

11. Moraes, M.; Debiasi, H.; Franchini, J.C.; Bonetti, J.A.; Levien, R.; Schnepf, A.; Leitner, D. Mechanical and hydric stress effects on maize root system development at different soil compaction levels. Front. Plant Sci. 2019, 10, 1358. [CrossRef] [PubMed]

12. Goulart, R.Z.; Reichert, J.M.; Rodrigues, M.F.; Chaiben Neto, M.; Ebling, E.D. Comparing tillage methods for growing lowland soybean and corn during wetter-than-normal cropping seasons. Paddy Water Environ. 2021, 19, 401-415. [CrossRef]

13. Abreu, S.L.; Reichert, J.M.; Silva, V.R.; Reinert, D.J.; Blume, E. Variabilidade espacial de propriedades físico-hídricas do solo, da produtividade e da qualidade de grãos de trigo em Argissolo franco arenoso sob plantio direto. Ciênc. Rural 2003, 33, 275-282. [CrossRef]

14. Collares, G.L.; Reinert, D.J.; Reichert, J.M.; Kaiser, D.R. Compactação de um latossolo induzida pelo tráfego de máquinas e sua relação com o crescimento e produtividade de feijão e trigo. Rev. Bras. Ciênc. Solo 2008, 32, 933-942. [CrossRef]

15. Secco, D.; Reinert, D.J.; Reichert, J.M.; da Silva, V.R. Atributos físicos e rendimento de grãos de trigo, soja e milho em dois Latossolos compactados e escarificados. Ciênc. Rural 2009, 39, 58-64. [CrossRef]

16. Bonini, A.K.; Secco, D.; Santos, R.F.; Reinert, D.J.; Reichert, J.M. Atributos físico-hidricos e produtividade de trigo em um Latossolo sob estados de compactação. Ciênc. Rural 2011, 41, 1543-1548. [CrossRef]

17. Collares, G.L.; Reinert, D.J.; Reichert, J.M.; Kaiser, D.R. Qualidade física do solo na produtividade da cultura do feijoeiro num Argissolo. Pesqui. Agropecu. Bras. 2006, 41, 1663-1674. [CrossRef]

18. Kaiser, D.R.; Reinert, D.J.; Reichert, J.M.; Collares, G.L.; Kunz, M. Intervalo hídrico ótimo no perfil explorado pelas raízes de feijoeiro em um latossolo sob diferentes níveis de compactação. Rev. Bras. Ciênc. Solo 2009, 33, 845-855. [CrossRef]

19. Reichert, J.M.; Suzuki, L.E.A.S.; Reinert, D.J.; Horn, R.; Håkansson, I. Reference bulk density and critical degree-of-compactness for no-till crop production in subtropical highly weathered soils. Soil Tillage Res. 2009, 102, 242-254. [CrossRef]

20. Reichert, J.M.; Rodrigues, M.F.; Awe, G.O.; Riquelme, U.F.B.; Kaiser, D.R.; Reinert, D.J. Common bean in highly variable weather conditions, on sandy soils, and food security in a subtropical environment. Food Energy Secur. 2015, 4, 219-237. [CrossRef]

21. Reichert, J.M.; Brandt, A.A.; Rodrigues, M.F.; da Veiga, M.; Reinert, D.J. Is chiseling or inverting tillage required to improve mechanical and hydraulic properties of sandy clay loam soil under long-term no-tillage? Geoderma 2017, 301, 72-79. [CrossRef]

22. Reichert, J.M.; da Silva, V.R.; Awe, G.O.; Wendroth, O.O.; Srinivasan, R. Defining tillage need for edible bean production under no-tillage: Classical and time series analyses. Soil Tillage Res. 2020, 202, 10467. [CrossRef]

23. Gubiani, P.I.; Reichert, J.M.; Reinert, D.J. Interação entre disponibilidade de água e compactação do solo no crescimento e na produção de feijoeiro. Rev. Bras. Ciênc. Solo 2014, 38, 765-773. [CrossRef]

24. Ferraz, L.L.; Silva, A.C.; Rocha, L.V.F.; Oliveira, T.M.S.; Silva, J.O. Influência da compactação do solo no desenvolvimento do sistema radicular do feijão (Phaseolus vulgaris L.). Agrar. Acad. 2017, 4, 166-174. [CrossRef]

25. Mentges, M.I.; Reichert, J.M.; Gubiani, P.I.; Reinert, D.J.; Xavier, A. Alterações estruturais e mecânicas de solo de várzea cultivado com arroz irrigado por inundação. Rev. Bras. Ciênc. Solo 2013, 37, 221-231. [CrossRef]

26. Goulart, R.Z.; Reichert, J.M.; Rodrigues, M.F. Cropping poorly-drained lowland soils: Alternatives to rice monoculture, their challenges and management strategies. Agric. Syst. 2020, 177, 102715. [CrossRef]

27. Fasinmirin, J.T.; Reichert, J.M. Conservation tillage for cassava (Manihot esculenta crantz) production in the tropics. Soil Tillage Res. 2011, 113, 1-10. [CrossRef]

28. Reichert, J.M.; Rodrigues, M.F.; Bervald, C.M.P.; Brunetto, G.; Kato, O.R.; Schumacher, M.V. Fragmentation, fiber separation, decomposition, and nutrient release of secondary-forest biomass, mechanically chopped-and-mulched, and cassava production in the Amazon. Agric. Ecosyst. Environ. 2015, 204, 8-16. [CrossRef]

29. Reichert, J.M.; Rodrigues, M.F.; Bervald, C.M.P.; Kato, O.R. Fire-free fallow management by mechanized chopping of biomass for sustainable agriculture in eastern amazon: Effects on soil compactness, porosity, and water retention and availability. Land Degrad. Dev. 2016, 27, 1403-1412. [CrossRef] 
30. Reichert, J.M.; Fontanela, E.; Awe, G.O.; Fasinmirin, J.T. Is cassava yield affected by inverting tillage, chiseling or additional compaction of no-till sandy-loam soil? Rev. Bras. Ciênc. Solo 2021, 45, e0200134. [CrossRef]

31. Reichert, J.M.; Morales, C.A.S.; Lima, E.M.; de Bastos, F.; Sampietro, J.A.; Cavalli, J.P.; de Araújo, E.F.; Srinivasan, R. Best tillage practices for early-growth of clonal eucalyptus in soils with distinct granulometry, drainage and profile depth. Soil Tillage Res. 2021, 212, 105038. [CrossRef]

32. Reichert, J.M.; Corcini, A.L.; Awe, G.O.; Reinert, D.J.; Albuquerque, J.A.; García Gallarreta, C.C.; Docampo, R. Onion-forage cropping systems on a Vertic Argiudoll in Uruguay: Onion yield and soil organic matter, aggregation, porosity and permeability. Soil Tillage Res. 2022, 216, 105229. [CrossRef]

33. Marins, A.C.; Reichert, J.M.; Secco, D.; Rosa, H.A.; Veloso, G. Crambe grain yield and oil content affected by spatial variability in soil physical properties. Renew. Sustain. Energy Rev. 2018, 81, 464-472. [CrossRef]

34. Awe, G.O.; Reichert, J.M.; Timm, L.C.; Wendroth, O.O. Temporal processes of soil water status in a sugarcane field under residue management. Plant Soil 2015, 387, 395-411. [CrossRef]

35. Awe, G.O.; Reichert, J.M.; Fontanela, E. Sugarcane production in the subtropics: Seasonal changes in soil properties and crop yield in no-tillage, inverting and minimum tillage. Soil Tillage Res. 2020, 196, e104447. [CrossRef]

36. Reichert, J.M.; Pellegrini, A.; Rodrigues, M.F. Tobacco growth, yield and quality affected by soil constraints on steeplands. Ind. Crops Prod. 2019, 128, 512-526. [CrossRef]

37. Reinert, D.J.; Albuquerque, J.A.; Reichert, J.M.; Aita, C.; Andrada, M.M.C. Limites críticos de densidade do solo para o crescimento de raízes de plantas de cobertura em Argissolo Vermelho. Rev. Bras. Ciênc. Solo 2008, 32, 1805-1816. [CrossRef]

38. Genro, S.A., Jr.; Reinert, D.J.; Reichert, J.M.; Albuquerque, J.A. Atributos físicos de um Latossolo Vermelho e produtividade de culturas cultivadas em sucessão e rotação. Ciênc. Rural 2009, 39, 65-73. [CrossRef]

39. Gomar Capurro, E.P.; Reichert, J.M.; Reinert, D.J.; García, F. Atributos do solo e biomassa radicular após quatro anos de semeadura direta de forrageiras de estação fria em campo natural dessecado com herbicidas. Rev. Bras. Ciênc. Solo 2002, 26, 211-223. [CrossRef]

40. Collares, G.L.; Reinert, D.J.; Reichert, J.M.; Kaiser, D.R. Compactação superficial de Latossolos sob integração lavoura: Pecuária de leite no noroeste do Rio Grande do Sul. Ciênc. Rural 2011, 41, 246-250. [CrossRef]

41. Kunz, M.; Gonçalves, A.D.M.A.; Reichert, J.M.; Guimarães, R.M.L.; Reinert, D.J.; Rodrigues, M.F. Compactação do solo na integração soja-pecuária de leite em Latossolo argiloso com semeadura direta e escarificação. Rev. Bras. Ciênc. Solo 2013, 37, 1699-1708. [CrossRef]

42. Gomar Capurro, E.P.G.; Secco, D.; Reichert, J.M.; Reinert, D.J. Compressibilidade e elasticidade de um Vertissolo afetado pela intensidade de pastejo bovino. Ciênc. Rural 2014, 44, 283-288. [CrossRef]

43. Ambus, J.V.; Reichert, J.M.; Gubiani, P.I.; de Faccio Carvalho, P.C. Changes in composition and functional soil properties in long-term no-till integrated crop-livestock system. Geoderma 2018, 330, 232-243. [CrossRef]

44. Holthusen, D.; Brandt, A.A.; Reichert, J.M.; Horn, R. Soil porosity, permeability and static and dynamic strength parameters under native forest/grassland compared to no-tillage cropping. Soil Tillage Res. 2018, 177, 113-124. [CrossRef]

45. Holthusen, D.; Brandt, A.A.; Reichert, J.M.; Horn, R.; Fleige, H.; Zink, A. Soil functions and in situ stress distribution in subtropical soils as affected by land use, vehicle type, tire inflation pressure and plant residue removal. Soil Tillage Res. 2018, 184, 78-92. [CrossRef]

46. Reichert, J.M.; Bervald, C.M.P.; Rodrigues, M.F.; Kato, O.R.; Reinert, D.J. Mechanized land preparation in eastern Amazon in fire-free forest-based fallow systems as alternatives to slash-and-burn practices: Hydraulic and mechanical soil properties. Agric. Ecosyst. Environ. 2014, 192, 47-60. [CrossRef]

47. Reichert, J.M.; Cechin, N.F.; Reinert, D.J.; Rodrigues, M.F.; Suzuki, L.E.A.S. Ground-based harvesting operations of Pinus taeda affects structure and pore functioning of clay and sandy clay soils. Geoderma 2018, 331, 38-49. [CrossRef]

48. Reichert, J.M.; Morales, C.A.S.; de Bastos, F.; Sampietro, J.A.; Cavalli, J.P.; Araújo, E.F.; Srinivasan, R. Tillage recommendation for commercial forest production: Should tillage be based on soil penetrability, bulk density or more complex, integrative properties? Geoderma Reg. 2021, 25, e00381. [CrossRef]

49. Sampietro, J.A.; Lopes, E.D.S.; Reichert, J.M. Compactação causada pelo tráfego de feller buncher e skidder em um Neossolo Regolítico sob distintas umidades. Ciênc. Florest. 2015, 25, 239-248. [CrossRef]

50. Suzuki, L.E.A.S.; Reichert, J.M.; Reinert, D.J.; de Lima, C.L.R. Degree of compactness and mechanical properties of a subtropical Alfisol with eucalyptus, native forest, and grazed pasture. For. Sci. 2015, 61, 716-722. [CrossRef]

51. França, J.S.; Reichert, J.M.; Holthusen, D.; Rodrigues, M.F.; de Araújo, E.F. Subsoiling and mechanical hole-drilling tillage effects on soil physical properties and initial growth of eucalyptus after eucalyptus on steeplands. Soil Tillage Res. 2021, 207 , 104860. [CrossRef]

52. Wang, X.; Shen, J.; Hedden, P.; Phillips, A.L.; Thomas, S.G.; Ge, Y.; Ashton, R.W.; Whalley, W.R. Wheat growth responses to soil mechanical impedance are dependent on phosphorus supply. Soil Tillage Res. 2021, 205, 104754. [CrossRef]

53. FAO. Voluntary Guidelines for Sustainable Soil Management; Food and Agriculture Organization of the United Nations: Rome, Italy, 2017; 16p, Available online: http:/ / www.fao.org/3/bl813e/bl813e.pdf (accessed on 9 July 2021).

54. Silva, S.M.A.; Locatelli, M.; Nunes, A.C.S.; Oliveira, C.P.; Sampaio, F.A.R.; Mandu, T.S.; Silva, C.A. Resistência mecânica do solo à penetração associado à umidade, densidade, granulometria e macronutrientes em Ji-Paraná-RO. Braz. J. Dev. 2021, 7, 5629-5647. [CrossRef] 
55. Queiroz, G.C.M.; Silva, F.W.A.; Portela, J.C.; Oliveira, V.N.S.; Santos, M.V. Densidade e resistência do solo à penetração de raízes em agroecossistemas no semiárido brasileiro. Rev. Verde 2019, 14, 497-505. [CrossRef]

56. Siqueira, P.G.S.; Ferro, M.G.F.; Santos, V.R.; Santos, M.A.L.; Silva, T.S.S.; Santos, C.G. Avaliação da resistência à penetração em um argissolo vermelho Distrófico. Rev. Ambient. 2019, 10,1-15. [CrossRef]

57. Spliethoff, J.; Rampim, L.; Pott, C.A.; Lustosa, S.B.C. Implicação de grades amostrais na determinação da resistência do solo à penetração e indicação de manejo. Res. Soc. Dev. 2020, 9, e790997871. [CrossRef]

58. Andrade, A.D.; Faria, R.O.; Alonso, D.J.C.; Ferraz, G.A.S.; Herrera, M.A.D.; Silva, F.M. Spatial variability of soil penetration resistance in coffee growing. Coffee Sci. 2018, 13, 341-348. Available online: http://www.coffeescience.ufla.br/index.php/ Coffeescience/article/view/1456 (accessed on 9 July 2021). [CrossRef]

59. De Maria, I.C.; Castro, O.M.; Dias, H.S. Atributos físicos do solo e crescimento radicular de soja em Latossolo Roxo sob diferentes métodos de preparo do solo. Rev. Bras. Ciênc. Solo 1999, 23, 703-709. [CrossRef]

60. Reichert, J.M.; Reinert, D.J.; Braida, J.A. Qualidade dos solos e sustentabilidade de sistemas agrícolas. Ciênc. Ambiente 2003, 27, 29-48.

61. Reichert, J.M.; Kaiser, D.R.; Reinert, D.J.; Riquelme, U.F.B. Variação temporal de propriedades físicas do solo e crescimento radicular de feijoeiro em quatro sistemas de manejo. Pesqui. Agropecu. Bras. 2009, 44, 310-319. [CrossRef]

62. Carneiro, K.A.A.; Oliveira, F.P.; Araujo, M.C.S.P.; Fernandes, L.F.; Abrantes, E.G.; Vendruscolo, J. Influência da compactação do solo no crescimento de milho (Zea mays L.) em Latossolo Vermelho-Amarelo. Colloq. Agrar. 2018, 14, 88-98. [CrossRef]

63. Taylor, H.M.; Roberson, G.M.; Parker, J.J., Jr. Soil strength-root penetration relations for medium to coarse-textured soil materials. Soil Sci. 1966, 102, 18-22. [CrossRef]

64. Canarache, A. Penetr-A generalized semi-empirical model estimating soil resistance to penetration. Soil Tillage Res. 1990, 16, 51-70. [CrossRef]

65. Beutler, A.N.; Centurion, J.F. Compactação do solo no desenvolvimento radicular e na produtividade da soja. Pesqui. Agropecu. Bras. 2004, 39, 581-588.

66. Beutler, A.N.; Centurion, J.F.; Centurion, M.A.P.C.; Silva, A.P. Efeito da compactação na produtividade de cultivares de soja em Latossolo Vermelho. Rev. Bras. Ciênc. Solo 2006, 30, 787-794. [CrossRef]

67. Vaz, C.M.P.; Manieri, J.M.; Maria, I.C.; van Genuchten, M.T. Scaling the dependency of soil penetration resistance on water content and bulk density of different soils. Soil Sci. Soc. Am. J. 2013, 77, 1488-1495. [CrossRef]

68. Silva, W.M.; Bianchini, A.; Cunha, C.A. Modelling and correction of soil penetration resistance for variations in soil moisture and soil bulk density. Eng. Agric. 2016, 36, 449-459. [CrossRef]

69. Jiang, Q.; Cao, M.; Wang, Y.; Wang, J. Estimating soil penetration resistance of paddy soils in the plastic state using physical properties. Agronomy 2020, 10, 1914. [CrossRef]

70. Abreu, S.L.; Reichert, J.M.; Reinert, D.J. Escarificação mecânica e biológica para a redução da compactação em argissolo francoarenoso sob plantio direto. Rev. Bras. Ciênc. Solo 2004, 28, 519-531. [CrossRef]

71. Bertollo, A.M.; Moraes, M.T.; Franchini, J.C.; Soltangheisi, A.; Balbinot, A.A., Jr.; Levien, R.; Debiasi, H. Precrops alleviate soil physical limitations for soybean root growth in an Oxisol from southern Brazil. Soil Tillage Res. 2021, 206, 104820. [CrossRef]

72. Jabro, J.D.; Allen, B.L.; Rand, T.; Dangi, S.R.; Campbell, J.W. Effect of previous crop roots on soil compaction in 2 yr rotations under a no-tillage system. Land 2021, 10, 202. [CrossRef]

73. Santos, H.G.; Jacomine, P.K.T.; Anjos, L.H.; Oliveira, V.A.; Lumbreras, J.F.; Coelho, M.R.; Almeida, J.A.; Araujo Filho, J.C.; Oliveira, J.B.; Cunha, T.J.F. Sistema Brasileiro de Classificação de Solos, 5th ed.; rev. e ampl.; Embrapa: Brasília, Brazil, 2018; 356p.

74. Soil Survey Staff. Keys to Soil Taxonomy, 12th ed.; USDA-Natural Resources Conservation Service: Washington, DC, USA, 2014. Available online: https://www.nrcs.usda.gov/wps/portal/nrcs/detail/soils/survey/class/taxonomy/?cid=nrcs142p2_053580 (accessed on 8 December 2021).

75. Wrege, M.S.; Steinmetz, S.; Reisser, C., Jr.; Almeida, I.R. (Eds.) Atlas Climático da Região Sul do Brasil: Estados do Paraná, Santa Catarina e Rio Grande do Sul, 2nd ed.; Embrapa: Brasília, Brazil, 2012.

76. Teixeira, P.C.; Donagemma, G.K.; Fontana, A.; Teixeira, W.G. (Eds.) Manual de Métodos de Análise de Solo, 3rd ed.; rev. e ampl.; Embrapa: Brasília, Brazil, 2017; 574p.

77. Suzuki, L.E.A.S.; Reichert, J.M.; Albuquerque, J.A.; Reinert, D.J.; Kaiser, D.R. Dispersion and flocculation of Vertisols, Alfisols and Oxisols in Southern Brazil. Geoderma Reg. 2015, 5, 64-70. [CrossRef]

78. National Resource Conservation Service-NRCS/United States Department of Agriculture-USDA. Soil Texture Calculator. Available online: https:/ / www.nrcs.usda.gov/wps / portal/nrcs/detail/?cid=nrcs142p2_054167 (accessed on 8 August 2020).

79. Baver, L.D. Practical values from physical analyses of soils. Soil Sci. 1949, 68, 1-14. [CrossRef]

80. Grable, A.R.; Siemer, E.G. Effects of bulk density, aggregate size, and soil water suction on oxygen diffusion, redox potential and elongation of corn roots. Soil Sci. Soc. Am. Proc. 1968, 32, 180-186. [CrossRef]

81. Correa, J.; Postma, J.A.; Watt, M.; Wojciechowski, T. Soil compaction and the architectural plasticity of root systems. J. Exp. Bot. 2019, 70, 6019-6034. [CrossRef]

82. Nagahama, H.J.; Cortez, J.W.; Pimenta, W.A.; Patrocinio Filho, A.P.; Souza, E.B. Resistência do solo à penetração em sistemas de preparo e velocidades de deslocamento do trator. Comun. Sci. 2016, 7, 56-65. [CrossRef]

83. Queiroz-Voltan, R.B.; Nogueira, S.S.S.; de Miranda, M.A.C. Aspectos da estrutura da raiz e do desenvolvimento de plantas de soja em solos compactados. Pesqui. Agropecu. Bras. 2000, 35, 929-938. [CrossRef] 
84. Rossetti, K.V.; Centurion, J.F. Indicadores de qualidade em Latossolos compactados e suas relações com o crescimento do sistema radicular do milho. Rev. Agro@Mbiente Online 2017, 11, 181-190. [CrossRef]

85. Unger, P.W.; Kaspar, T.C. Soil compaction and root growth: A review. Agron. J. 1994, 86, 759-766. [CrossRef]

86. Reichert, J.M.; da Rosa, V.T.; Vogelmann, E.S.; da Rosa, D.P.; Horn, R.; Reinert, D.J.; Sattler, A.; Denardin, J.E. Conceptual framework for capacity and intensity physical soil properties affected by short and long-term (14 years) continuous no-tillage and controlled traffic. Soil Tillage Res. 2016, 158, 123-136. [CrossRef] 